\title{
Provenance discrimination of siliciclastic sediments in the middle Okinawa Trough since 30 ka: Constraints from rare earth element compositions
}

\author{
Yanguang Dou ${ }^{a}$, Shouye Yang ${ }^{a,{ }^{*}}$, Zhenxia Liu ${ }^{b}$, Peter D. Clift ${ }^{c}$, Xuefa Shi ${ }^{b}$, Hua Yu ${ }^{b}$ and Serge Berne ${ }^{d}$ \\ a State Key Laboratory of Marine Geology, Tongji University, Shanghai 200092, China \\ ${ }^{\mathrm{b}}$ First Institute of Oceanography, State Oceanic Administration, Qingdao 266071, China \\ ${ }^{c}$ School of Geosciences, University of Aberdeen, Meston Building, Aberdeen AB24 3UE, United Kingdom \\ d IFREMER, DRO/GM, P.O. Box 70, 29280 Plouzané, France \\ *: Corresponding author : Shouye Yang, Tel.: +86 216598 9130; fax: +86 216598 6278, email address : \\ syyang@tongji.edu.cn
}

\begin{abstract}
:
The late Quaternary paleoceanography and paleoenvironment in the Okinawa Trough, East China Sea, have been well reconstructed over the last decade, while in contrast the provenance of terrigenous sediments that have accumulated there remains enigmatic. In this study, rare earth elements (REE) were used to investigate provenance changes in sediments from Core DGKS9604, taken from the middle Okinawa Trough. Discrimination plots based on REE fractionation parameters suggest that the cored sediments have variable provenances over the last $30 \mathrm{ka}$, with the lower part (ca. 31-8.2 ka) ultimately originating mostly from the Changjiang (Yangtze River) and the upper part (7.1-0 ka) primarily from Taiwan. During the Last Glacial Maximum and early deglacial period, sea level was low and the main stream of the Kuroshio Current was deflected to the east of the Ryukyu Islands. As a result the Changjiang-derived sediments might have dominated sedimentation of the middle Okinawa Trough. However, since about $7 \mathrm{ka}$ the main stream of the Kuroshio Current strengthened in the area of the trough, as sea level approximated the modern position. This caused near-bottom transport of fine-grained sediments from the continental margin to the trough to become weak and instead, Taiwan-derived terrigenous sediments dominated in the middle trough. The changing provenances of terrigenous sediments into the middle Okinawa Trough are closely related to the evolution of oceanic circulation and sea level in the East China Sea. Two tephra layers in the core have distinct REE compositions and correlate well with two volcanic eruptions at 7.6 and $25.8 \mathrm{ka}$ in southern Japan.
\end{abstract}

Keywords: sediment provenance; the Okinawa Trough; Kuroshio Current; rare earth element 


\section{Introduction}

The Okinawa Trough is located in the southeast of the East China Sea and is regarded as an incipient intra-continental basin formed behind the Ryukyu arc-trench system (Clift et al., 2003)(Fig. 1). The continuous sedimentation during the late Quaternary in the Okinawa Trough has been regulated by changing terrigenous sediment supply, sea level, oceanic circulation and the intensity of the East Asian monsoon. As a result the sediment distribution, transport and dispersal patterns in the Trough and adjoining shelf are closely related to these complex controlling factors. In view of this, the Okinawa Trough is an ideal natural laboratory in the Western Pacific marginal seas for the studies of late Quaternary land-sea interaction and paleoenvironmental changes.

Over the last two decades, many scientists have attempted to identify the origin of sediment in the middle Okinawa Trough using mineralogical (Chen et al., 1982; Dou et al., 2010), oceanographic and paleoceanographic (Jian et al., 1998, 2000; Ujiié and Ujiié, 1999; Liu et al., 1999, 2000; Liu, 2005), environmental magnetic (Liu et al., 2007), as well as geochemical methods (Zhao and Yan, 1992; Meng et al., 2007). These studies suggested that the terrigenous sediment sources of the Okinawa Trough predominantly include direct supply from major rivers in East Asia, particularly the Changjiang (Yangtze River) and Huanghe (Yellow River) (Katayama and Watanabe, 2003), and lateral transport from the East China Sea shelf through the bottom layers (Honda et al., 2000; Iseki et al., 2003; Oguri et al., 2003). In particular, during the Last Glacial Maximum (LGM) when the sea level was about $120 \mathrm{~m}$ lower than in the present day, Changjiang-derived sediments must have directly emptied into the Okinawa Trough (Milliman et al., 1989; Saito et al., 1998; Yoo et al., 2002; Liu et al., 
2007; Dou et al., 2010). In addition, the episodic volcanic eruptions in the west Japan volcanic zone have produced widespread fallout tephra layers in the northern Okinawa Trough (Machida, 1999; Miyairi et al., 2004). Other factors such as submarine hydrothermal activity (Zhai et al., 2001), erosion of tectonically active Taiwan Island (Liu et al., 2008), aeolian transport (Tsunogai et al., 1985), seafloor earthquakes (Huh et al., 2004), as well as intrusion of the Kuroshio Current (Jian et al., 1998; Lee et al., 2004) also contribute to the transport of siliciclastic sediments into and within the trough.

Nevertheless, the ultimate origin of sediment in the Okinawa Trough still remains unresolved at present despite many research efforts (Hu et al., 2001; Katayama and Watanabe, 2003). Sedimentation in the middle Okinawa Trough is primarily controlled by Changjiang diluted waters, the Asian winter monsoon winds that originate from the northwest of China, as well as the Kuroshio Current, which is derived from the northern equatorial current. Whether the Changjiang (and/or Huanghe) - derived particulate materials can directly reach the Okinawa Trough in the present day or during the LGM remains controversial (Li and Zhang, 1995; Oguri et al., 2003). It has been documented that the terrigenous sediments may have been laterally transported from the East China Sea shelf to the trough after sea level reached its highstand during the Holocene (Iseki et al., 2003; Liu et al., 2007). However, the Kuroshio Current strengthened and its main stream returned to the Okinawa Trough at about 7 ka (Jian et al., 2000), which might have significantly reduced the sediment transport at the bottom from the continental shelf of the East China Sea to the trough because of a "water barrier" effect (Guo et al., 2001). Whether and how far the terrigenous sediments from Taiwan Island can be transported northward into the middle and northern Okinawa Trough is another challenging 
question waiting for more lines of evidences (Hsu et al., 2004).

The reliable provenance tracers of terrigenous sediments from different end-members and high-resolution sampling analysis are urgently needed if the sediment transport patterns in and around the Okinawa Trough are to be understood in detail. Geochemical approaches have been proven to be powerful in identifying sediment provenances in the East Asian marginal seas (Clift et al., 2002, 2006; Yang et al., 2004, 2008; Choi et al., 2007; Yan et al., 2007). Among the various methods, rare earth elements (REEs) have been well accepted as reliable provenance tracers because they behave conservatively during sediment formation being largely water-immobile (Taylor and McLennan, 1985). The main research objectives of this paper are to 1) characterize the REE compositions of sediments from Core DGKS9604 taken from the middle Okinawa Trough; 2) identify the provenance changes of siliciclastic sediments since $30 \mathrm{ka}$; and 3) discuss the competing roles of sea level change, monsoon variability and Kuroshio Current strength and location in regulating the terrigenous sediment inputs into the middle trough.

\section{Samples and method}

A piston core (DGKS9604) was taken from the middle Okinawa Trough $\left(28^{\circ} 16.64^{\prime} \mathrm{N}, 127^{\circ} 01.43^{\prime} \mathrm{E}\right)$ at a water depth of $766 \mathrm{~m}$ during the joint Chinese-French DONGHAI Cruise in 1996 (Fig. 1). The core is $1076 \mathrm{~cm}$ long and located on the western continental slope of the middle Okinawa Trough. Different from the adjacent core DGKS9603 $\left(28^{\circ} 08.869^{\prime} \mathrm{N}, 127^{\circ} 16.238^{\prime} \mathrm{E}\right)$, which was taken during the same cruise (Fig.1), no visual ash layers and hiatuses are present in Core DGKS9604 (Yu et al., 2008, 2009). A high-resolution age model of the core was established on the basis of the oxygen isotopic compositions of Globigerinoides sacculifer and accelerator 
mass spectrometry (AMS) radiocarbon dating of planktonic foraminifera (Liu et al., 2001; Yu et al., 2009). The depositional age at the bottom of the core is estimated to be $37.0 \mathrm{Cal} \mathrm{ka}$, and the bulk sedimentation rate of the core averages about $29 \mathrm{~cm} / \mathrm{k} . \mathrm{y}$, which is higher than that of Core DGKS9603 (Liu et al., 1999, 2000). Sediments from Core DGKS9604 are primarily composed of clayey silt, with a mean grain size of 6.7 $\pm 0.4 \Phi$ (Yu et al., 2008; Dou et al., 2010; Fig. 2). The paleoceanography and clay mineralogy of this core have been recently reported elsewhere (Yu et al., 2008, 2009; Dou et al., 2010).

A total of 106 subsamples were collected from Core DGKS9604 at $4 \mathrm{~cm}$ intervals for the uppermost $100 \mathrm{~cm}$ and at $8 \mathrm{~cm}$ intervals between 100 and $743 \mathrm{~cm}$. To separate the residual fractions from the bulk samples, about $0.2 \mathrm{~g}$ bulk sediment samples were leached with $20 \mathrm{~mL} 1 \mathrm{~N} \mathrm{HCl}$ (hydrochloric acid) for 24 hours at $50^{\circ} \mathrm{C}$. In this study we followed the $1 \mathrm{~N} \mathrm{HCl-leaching} \mathrm{method} \mathrm{by} \mathrm{Choi} \mathrm{et} \mathrm{al.} \mathrm{(2007).} \mathrm{Recent} \mathrm{work} \mathrm{by}$ Song and Choi (2009) also used this method to leach the river sediments for separating different phases of bulk REE concentrations. The residues of the leached samples were rinsed using deionized water, and then heated to dryness at $50^{\circ} \mathrm{C}$. All the residual samples were combusted in the muffle furnace for two hours at $600{ }^{\circ} \mathrm{C}$ before the acid digestion. About $50 \mathrm{mg}$ powdered samples were digested with $4 \mathrm{ml} \mathrm{HNO}_{3}$ and $1 \mathrm{ml} \mathrm{HClO}_{4}$ for 24 hours in a tightly closed Teflon vessel on a hot plate at less than $150{ }^{\circ} \mathrm{C}$, heated to dryness, and then digested with a mixture of $4 \mathrm{ml} \mathrm{HF}$ and $1 \mathrm{ml}$ $\mathrm{HClO}_{4}$. Afterwards, the solution was evaporated to dryness, and extracted with $10 \mathrm{ml}$ $1 \% \mathrm{HNO}_{3}$. The digestion method for measuring $\mathrm{REE}$ concentrations in river sediments was previously reported by Yang et al. (2002). Concentrations of REEs and other elements in the residual fractions were determined by ICP-MS (PQ3, Thermo Elemental) and ICP-AES (IRIS Advantage) in the State Key Laboratory of Marine 
Geology at Tongji University. The precision and accuracy were monitored by national geostandards GSR-5, GSR-6, and GSR-9 provided by National Research Center for Geoanalysis. For REE analysis, the differences between the determined and certified values of these geostandards were less than 5\%. The leaching efficiency of $1 \mathrm{~N} \mathrm{HCl}$ was checked by measuring the concentrations of major elements in the leached and residual fractions of GSR-5, GSR-6, and GSR-9. The recoveries of the measured total concentrations were estimated to above $90 \%$.

A total of 188 subsamples were selected for calcium carbonate analysis using an element analyzer (Carlo-Erba model EA1110, Italy). All the samples were pretreated with $1 \mathrm{~N} \mathrm{HCl}$ to remove calcium carbonate to measure the total organic carbon (TOC) contents of the residual fractions, and then, measure the total carbon (TC) contents of bulk samples. The contents of calcium carbonate were estimated by the TC and TOC contents: $\mathrm{CaCO}_{3}(\%)=(\mathrm{TC}-\mathrm{TOC}) \times 100 / 12$. For monitoring the analytic error, the pure organic compounds including Crystine, Sulphanilamide and Methionine were used as standards, which yielded a precision of about $0.3 \%$.

\section{Results and discussions}

\subsection{REE compositions of the Core DGKS9604 sediments}

The average compositions of rare earth elements in the Core DGKS9604 sediments and the reference materials are given in Table 1, and the raw data see the background dataset. Depth profiles of total REE concentrations, REE fractionation parameters, $\mathrm{CaCO}_{3}$ contents and mean grain size are shown in Figure 2. The anomalies of cerium $(\delta \mathrm{Ce})$ and europium $(\delta \mathrm{Eu})$ as two important REE parameters, were calculated by comparing the measured concentrations of $\mathrm{Ce}$ and Eu with their neighboring elements: $\delta \mathrm{Ce}=\mathrm{Ce}_{\mathrm{N}} / \sqrt{ }\left[\left(\mathrm{La}_{\mathrm{N}}\right) \cdot\left(\mathrm{Pr}_{\mathrm{N}}\right)\right] ; \delta \mathrm{Eu}=\mathrm{Eu}_{\mathrm{N}} / \sqrt{ }\left[\left(\mathrm{Sm}_{\mathrm{N}}\right) \cdot\left(\mathrm{Nd}_{\mathrm{N}}\right)\right]$, where $\mathrm{N}$ represents the normalization of chondrite. 
The REE compositions, including total REE concentrations, (La/Yb) $)_{\mathrm{UCC}}$, $175(\mathrm{La} / \mathrm{Sm})_{\mathrm{UCC}},(\mathrm{Gd} / \mathrm{Yb})_{\mathrm{UCC}}, \delta \mathrm{Ce}$ and $\delta \mathrm{Eu}$, exhibit regular variations in the core with a remarkable and abrupt change occurring in the mid-Holocene (8.2-7.1 ka) (Fig. 2). The upper and younger sediments (Unit 1, 0-142 $\mathrm{cm}$ and deposited since $7.1 \mathrm{ka}$ ) are significantly enriched in REE concentrations and characterized by lower values of $(\mathrm{La} / \mathrm{Yb})_{\mathrm{UCC}},(\mathrm{La} / \mathrm{Sm})_{\mathrm{UCC}}, \delta \mathrm{Ce}$ and $\delta \mathrm{Eu}$ compared to the underlying and older sediments (Unit 2, 158-743 cm, deposited during 8.2-30.3 ka). However, (Gd/Yb) $)_{U C C}$ ratios, are relatively higher in Unit 1 than in Unit 2 . In contrast to the REE compositions, the oxygen isotopic values $\left(\delta^{18} \mathrm{O}\right)$ of foraminifera, $\mathrm{CaCO}_{3}$ contents and mean grain size of the sediments show large variations at the boundary between oxygen isotope stages (OIS) 1 and 2 at about $10 \mathrm{ka}$ (Fig. 2), yet this change does not affect the source of the siliciclastic component.

The upper continental crust (UCC, Taylor and McLennan, 1985)-normalized REE patterns of Core DGKS9604 sediments show significant fractionations of the middle REE (specially Gd and Eu), as shown by higher values of (Gd/Yb) UCC relative to $(\mathrm{La} / \mathrm{Yb})_{\mathrm{UCC}}$ and (La/Sm) UCC (Table 1; Fig.2). In addition, different UCC-normalized REE patterns occur between Unit 1 and Unit 2, and it is noteworthy that Gd (gadolinium) anomalies apparently occur in the UCC-normalized REE patterns of the core sediments (Figs. 3, 4). Gadolinium anomaly in river sediments was once suggested to be of anthropogenic origin (Bau and Dulski, 1996). However, the Gd anomalies occurring in the modern fluvial sediments of the Changjiang and Huanghe do not reflect anthropogenic origin but indicate natural middle REE fractionation probably caused by specific minerals (Yang et al., 2002).

Overall, Unit 1 shows relative enrichments in total REE and remarkable fractionations of middle and heavy REEs, with obvious convex shapes in the REE 
plots, whereas Unit 2 is characterized by relatively flat REE patterns, without obvious Ce and Eu anomalies (Fig. 3).

Two layers with much lower than normal values of $(\mathrm{La} / \mathrm{Yb})_{\mathrm{UCC}},(\mathrm{La} / \mathrm{Sm})_{\mathrm{UCC}}$ and $(\mathrm{Gd} / \mathrm{Yb})_{\mathrm{UCC}}$ occur at core depths of $150 \mathrm{~cm}$ and $575 \mathrm{~cm}$ respectively (Fig. 2). The AMS ${ }^{14} \mathrm{C}$ ages of these two layers are about $7.6 \mathrm{ka}$ and $25.8 \mathrm{ka}$ respectively, which correspond well with two volcanic eruption events documented in southwestern Japan (Kitagawa et al., 1995; Arakawa et al., 1998).

\subsection{Controlling factors of REE compositions in the core sediments}

Many factors, including bed rock composition in the provenance area, sediment grain size, mineralogy, intensity of chemical weathering, diagenesis and anthropogenic activity are all responsible for REE compositions in sediments. Among these competing processes, sediment provenance is regarded as the most important control over REE compositions (Taylor and McLennan, 1985; Condie, 1991; Yang et al., 2002; Song and Choi, 2009), at least in the case of the present study. It has been well documented that REE are generally enriched in clay and silt fractions, but depleted in sand fractions, because of dilution by quartz and carbonate minerals (McLennan, 1989; Vital et al., 1999). The Core DGKS9604 sediments are primarily composed of clayey silt with an average grain size ranging from $7.2 \Phi$ to $6.3 \Phi$ (Yu et al., 2008). Poor correlations are observed between mean grain size, REE concentrations and fractionation parameters (Fig. 2), suggesting that the sediment grain size is not an important factor for controlling the REE concentrations in the sediments we analyzed from the middle Okinawa Trough.

In this study, $1 \mathrm{~N} \mathrm{HCl}$ was used to leach the bulk sediment samples and the residual fractions were separated for measuring REE concentrations. Therefore, we infer that a major part of the mobile fraction, including carbonate, apatite, and Fe-Mn 
oxides were removed from the bulk core sediments (Yang et al., 2002; 2006; Choi et al., 2007; Song and Choi, 2009), and thus that the measured REE compositions overall represent the contributions of the siliciclastic fraction to the core sediments. Chemical weathering thus exerts a weak influence on the REE compositions in the residual fractions.

Heavy minerals such as zircon, monazite, garnet, allanite and sphene, despite their low abundances in sediments, may account for a considerable fraction of the bulk REE concentrations because of the high REE concentrations in these minerals (Gromet and Silver, 1983; Tayor and McLennan, 1985; McLennan, 1989; Hannigan and Sholkovitz, 2001). However, recent study suggested that major rock-forming and heavy minerals in total contribute less than $20 \%$ of the total REE concentrations in the modern Changjiang riverine sediments (Yang et al., 2002). The mean sediment grain size of Core DGKS9604 ranges from $7.2 \Phi$ to $6.3 \Phi$, smaller than that of the Changjiang sediment $(6.3 \pm 0.4 \Phi)$, which suggests that heavy minerals are probably not the primary control on REE compositions in the core sediments. Consequently, variations of REE concentrations, as well as fractionation patterns in the siliciclastic sediments, should reflect the bulk mineralogy and so clearly indicate changes of sediment provenance.

\subsection{Provenance discrimination of the Core DGKS9604 sediments}

Because of the lower contents of biogenic silica from radiolarians and diatoms and authigenic components (Fe-Mn oxides) in the west slope of the Okinawa Trough (Liu, 2005), the residues of $1 \mathrm{~N} \mathrm{HCl}$ leached samples studied in this paper are primarily composed of detrital silicate minerals, which mainly originated from erosion of terrigenous and volcanic sources. The potential provenances of siliciclastic sediments 
in the middle Okinawa Trough include terrigenous sources supplied via fluvial and eolian inputs, volcanic and hydrothermal activities, and those carried by the oceanic currents such as the Kuroshio Current from the southern Okinawa Trough. It has long been recognized that the terrigenous particulate matters into the middle and north Okinawa Trough are mainly derived from the shelf of the East China Sea where the sediments predominantly originate from the two largest rivers in China, i.e. Changjiang and Huanghe Rivers (Qin et al., 1987; Iseki et al., 2003; Katayama and Watanabe, 2003; Liu et al., 2007; Dou et al., 2010). Further south however Taiwan dominates because it is one of the greatest producers of terrigenous sediment to the ocean known globally (Milliman and Syvitski, 1992).

259 Compared to the surface seafloor sediments in the East China Sea, Core 260 DGKS9604 sediments have higher REE concentrations, ratios of $(\mathrm{La} / \mathrm{Yb})_{\mathrm{UCC}}$ and $(\mathrm{La} / \mathrm{Sm})_{\mathrm{UCC}}$, and lower of $(\mathrm{Gd} / \mathrm{Yb})_{\mathrm{UCC}}($ Table 1). Nevertheless, a detailed comparison of REE composition between the sediments from the continental shelf of the East China Sea and from the Core DGKS9604 can not be made because of inadequate data

264 from the East China Sea and different sample pre-treatment methods. Significant differences in REE concentrations and fractionation patterns between Unit 1 and Unit 2 suggest that these depositional units may have different sediment provenances. Unit 2 sediments have REE compositions that are more similar with the modern 268 Changjiang, rather than Huanghe sediments, in terms of their REE concentrations and 269 fractionation parameters (Table 1, Fig 4a). In contrast, Unit 1 sediments have much higher total REE concentrations and different REE fractionation patterns compared to 271 Unit 2 (Table 1; Figs. 2-4). In this study, a discrimination plot of ( $\mathrm{La} / \mathrm{Sm})_{\mathrm{UCC}}$ vs. $272(\mathrm{Gd} / \mathrm{Yb})_{\mathrm{UCC}}$ was used to identify the provenance of sediment in Core DGKS9604 (Fig. 273 5). The figure clearly demonstrates that the Unit 2 sediments plot together with the 
274 Changjiang sediments, whereas the Unit 1 sediments plot in another group that is 275 close in character to the sediments from southwestern Taiwan (Chen et al., 2007). 276 Therefore, we infer that the older sediments (Unit 2, 158-743 cm, deposited at $277 \quad 8.2-30.3 \mathrm{ka}$ ) were derived predominantly from the Changjiang and partly from the 278 Huanghe, while the upper core sediments (Unit 1, 0-142 cm, deposited at 0-7.1 ka) were primarily sourced from Taiwan Island.

Volcanic materials derived from the sea floor or transported from the volcanoes of the Japanese islands also exert significant influence on the deposition in the middle Okinawa Trough, and therefore, can be considered as another potential contributor to 283 the terrigenous detritus (Machida, 1999). Several tephra layers occurring in the 284 sediments of the north Okinawa Trough are mainly composed of volcanic glasses and pumices (Xu and Oda, 1999; Ujiié et al., 2001; Sun et al., 2003). Two abnormal layers deposited at $7.6 \mathrm{ka}$ and $25.8 \mathrm{ka}$ have extraordinarily strong HREE enrichment and LREE depletion (Figs. 3, 4b), very similar to the surrounding volcanic materials which came from the Kyushu islands of Southwestern Japan (Figs. 1, 4b) (Arakawa et al., 1998; Hamasaki, 2002), but much different from the other core sediment and the riverine sediments of the Changjiang and Huanghe (Figs. 3, 4a). This clearly suggests that these two layers with abnormal REE compositions in Core DGKS9604 predominantly consist of volcanic materials. Two volcanic events, known as are known in southwest Japan (Fig. 1). They were regarded as the origin of two widely distributed tephra layers in the sediments of the middle and north Okinawa Trough, which predominantly consist of volcanic glasses and pumices $(\mathrm{Xu}$ and Oda, 
abnormal layers in Core DGKS9604 are thus estimated to be dominated by K-Ah tephra and AT tephra, especially considering that they have similar ages.

301 The average REE concentrations of the volcanic glass (Liu and Meng, 2004) and volcanic rocks around the southwestern Japan Island (Shinjo and Kato, 2000) are 93.7

$303 \mu \mathrm{g} / \mathrm{g}$ and $109.6 \mu \mathrm{g} / \mathrm{g}$ respectively, much lower than those found in this core, or in 304 sediments from the Changjiang and Huanghe Rivers (Table 1). Indeed, the total REE concentrations of these two layers are $174.0 \mu \mathrm{g} / \mathrm{g}$ and $129.0 \mu \mathrm{g} / \mathrm{g}$ respectively, much higher than those of the documented volcanic materials, which implies that these two tephra layers are probably mixed with other terrigenous sediments, which have higher

308 REE concentrations. The discrimination plot suggests that the abnormal layer 1 deposited at 7.6 ka was probably K-Ah tephra mixed with fine-grained terrigenous sediments from Taiwan, while abnormal layer 2, which was deposited at $25.8 \mathrm{ka}$ was

311 formed by mixture between the AT tephra and riverine sediments from mainland

312 China (Fig. 5). In addition, no visual volcanic glasses and pumices were observed in 313 the core sediments (Yu et al., 2008, 2009), further suggesting that the volcanic 314 materials from the surrounding islands might not have dominated the late Quaternary 315 sedimentation in the middle Okinawa Trough.

3.4 Transport pattern of detrital sediments into the middle Okinawa Trough during the last $30 \mathrm{ka}$

319 The identification of sediment sources in the Okinawa Trough is of great 320 significance for understanding the depositional history and paleoenvironmental 321 changes of the East China Sea during the late Quaternary. REE concentrations and 322 fractionation patterns strongly suggest that the siliciclastic sediments accumulated in 323 the middle Okinawa Trough during the late Quaternary might originate from different 
provenances. During the period from late last glaciation $(30 \mathrm{ka})$ to the early-middle Holocene $(8.0 \sim 7.0 \mathrm{ka})$ the Changjiang was the primary sediment supplier, whereas during the late Holocene of the last $7 \mathrm{ka}$ Taiwan Island could be the dominant sediment supplier. The provenance discrimination results based on REE compositions are basically similar with the observation of clay mineral assemblages (Dou et al., 2010).

The lowest sea level during the Last Glacial Maximum (LGM) was about 120 135 m lower than that of today (Emery et al., 1971; Qin et al., 1987; Henderson, 2002), which implies that the continental shelf of the East China Sea would have been largely exposed and correspondingly, that the river mouths of the paleo-Changjiang and/or paleo-Huanghe must have been positioned significantly closer to present-day's outer shelf (Fig. 6a). Furthermore, the main stream of the Kuroshio Current deflected to the east of the Ryukyu Islands Arc during the LGM (Ujiié et al., 1991; Ahagon et al., 1993; Xiang et al., 2003) (Fig. 6a). As a result, the terrigenous fine-grained particulate materials from the Changjiang and/or Huanghe might have been transported directly into the middle Okinawa Trough and dominated the deposition there, since there would have been no influence from the Kuroshio Current.

Previous studies suggested that the aeolian input from the loess area in western China into the East Asian marginal seas increased during the LGM (Irino and Tada, 2002; Nagashima et al., 2007). It is well known that the Huanghe sediments have very similar REE compositions with the loess because the latter is the main sediment provider of the Huanghe (Yang et al., 2002). The Unit 2 and Huanghe sediments plot in different groups in the discrimination plot (Fig. 5), suggesting that the Huanghe-derived and aeolian materials did not contribute significantly to the siliciclastic deposition in the middle Okinawa Trough during the LGM. 

retreated with the postglacial sea-level rising to its present position at about $6 \sim 7 \mathrm{ka}$ (Liu et al., 2007). The main stream of the Kuroshio Current re-entered the Okinawa Trough and/or strengthened at about 7.5-6.0 ka, and the modern oceanic circulation in the East China Sea was finalized at that time (Ujiié et al., 1991; Jian et al., 1998, 2000; Xiang et al., 2003). Since then, sedimentation in the Okinawa Trough has been dominated by the competing processes of the Kuroshio Current and the oceanic circulations in the East China Sea (Lee et al., 2004). Sediment trap experiments revealed that a significant amount of suspended terrigenous particles are transported through the bottom layer from the outer shelf of the East China Sea to the Okinawa Trough (Iseki et al., 2003; Katayama and Watanabe, 2003). Near-bottom transport may be a key process for shelf-to-deep sea export of biogenic/lithogenic particles (Iseki et al., 2003).

The REE compositions of the Unit 1 sediments are remarkably different from the Unit 2 and riverine sediments from mainland China, but very similar with those of Taiwan-derived sediments (Table 1; Figs. 2 and 5). This implies that the siliciclastic sediments deposited since $7 \mathrm{ka}$ in the middle Okinawa Trough were primarily sourced from Taiwan, and probably transported northward by the main stream of the Kuroshio Current, after their initial deposition from the Lanyang River delta and fan. In contrast, the sediment transport through the bottom layer from the outer shelf of the East China Sea to the middle Okinawa Trough during the late Holocene was relatively weak as a result of the blocking effect of the Kuroshio and Taiwan Warm Currents, which act as a barrier deflecting other currents from the area (Fig. 6b). Therefore, the suspended or resuspended fine-grained sediments of the Changjiang and/or Huanghe would not have been able to dominate the sedimentation in the middle Okinawa Trough since the 
high stand of sea level at ca. $6 \sim 7 \mathrm{ka}$.

The basins offshore northeastern Taiwan experience an extremely energetic sediment transport regime due to the passage of the Kuroshio Current and its interaction with the high rugged bathymetry in the southern trough. Annual loading of riverine suspended particulate matter from northern Taiwan (ca. $2 \times 10^{7}$ ton $_{\mathrm{yr}^{-1}}$ ) makes the island an important source for sediments to the subduction margin accretionary wedge (Hung et al., 1999; Dadson et al., 2003). The sediments in the Southern Okinawa Trough have been suggested to be primarily derived from the Lanyang River in northern Taiwan and other eastern Taiwanese rivers, transported by the Kuroshio Current (Hsu et al., 2004; Jian et al., 2000; Jeng et al., 2003; Huh et al., 2004; Lee et al., 2004). Due to the lack of end-member data of Taiwan rivers, in the present study we can not make a detailed and direct comparison of REE composition between the core and Taiwan riverine sediments. Nevertheless, the discrimination plot implies that the Taiwan-derived fine-grained sediments might have contributed considerably to the middle Okinawa Trough since the middle Holocene.

It is interesting to note that the REE compositions of Core DGKS9604 sediments do not vary simultaneously with the oxygen isotopes of foraminifera or with bulk $\mathrm{CaCO}_{3}$ compositions, which show abrupt and large variations at ca. $10 \mathrm{ka}$ (Fig. 2). For example, the oxygen isotopes of foraminifera and bulk $\mathrm{CaCO}_{3}$ show heavier and lower values respectively during the LGM than in the Holocene (Fig. 2) (Jian et al., 2000; Liu et al., 2001). The relatively uniform REE compositions of the Unit 2 sediments suggest that from ca. 30 to $7.0 \mathrm{ka}$ the provenances of the terrigenous sediments of the middle Okinawa Trough remained stable, despite large fluctuations of sea level, monsoon activity and depositional environments as well. In comparison, the oxygen isotopes of foraminifera and bulk $\mathrm{CaCO}_{3}$ compositions in the core 
sediments that reflect the in-situ paleoenvironment and primary productivity are more sensitive to changing sea level, depositional environments and/or monsoon activity during the late Quaternary. The depositional flux of REE to the Core DGKS9604 sediments varied significantly since $30 \mathrm{ka}$, shown by higher fluxes at 30-22, 17.8-11.8, 6-4, and 2-0 ka and were lower at 22-17.8, 11.8-6.0, 4-2 ka (Fig. 2). The variable depositional fluxes of REE strongly suggests that the changing supply rates of terrigenous sediments into the middle Okinawa Trough during the late Quaternary, were probably related to the weathering intensity and sediment production in the large drainage basins. However, it is noteworthy that other factors control the REE flux at the core location, most notably the distance of the river mouth from the middle Okinawa Trough and transport processes of fine-grained sediments in the continental margin (Meng et al., 2007). In particular, we note that 11.8-6.9 ka is a period of lower REE flux, yet this time is generally recognized as a period of strengthening summer monsoon rains (Wang et al., 2001; Herzschuh, 2006). If stronger summer monsoon rains were driving stronger continental erosion, as has been seen in South Asia (Clift et al., 2008), then the sedimentation should increase not decrease. Probably, major part of these increased terrigenous sediments resulted from stronger continental erosion was trapped in the continental shelf with rapidly rising sea level during the early postglacial period. Nevertheless, the controls of depositional flux of terrigenous sediments in the middle Okinawa Trough is beyond this study and will not be considered in greater detail in this paper.

\section{Conclusions}

One hundred and six sub-samples of Core DGKS9604, which spans the past 30 
424 k.y. and comprises clayey silt, were collected from the middle Okinawa Trough for sediment provenance study. Based on REE geochemical characteristics of the residual fractions leached by $1 \mathrm{~N} \mathrm{HCl}$, we conclude that Core DGKS9604 can be divided into an upper Unit $1(0-142 \mathrm{~cm},<7.1 \mathrm{ka})$ and Unit $2(158-743 \mathrm{~cm}, 8.2-30.3 \mathrm{ka})$. Total REE concentrations and fractionation parameters, including $(\mathrm{La} / \mathrm{Yb})_{\mathrm{UCC}},(\mathrm{La} / \mathrm{Sm})_{\mathrm{UCC}}$, $(\mathrm{Gd} / \mathrm{Yb})_{\mathrm{UCC}}, \mathrm{Ce}$ and Eu anomalies, are significantly different between Units 1 and 2, with large and abrupt variations occurring at 8.2-7.1 ka. The UCC-normalized REE patterns of the Unit 2 sediments are very similar with those of the riverine sediments from mainland China, especially from the Changjiang. This observation suggests that the fine-grained terrigenous sediments which accumulated in the middle Okinawa Trough from LGM to the middle Holocene might originate predominantly from the Changjiang. During that period, the main stream of the Kuroshio Current was deflected to the east of the Ryukyu Islands and the sea level remained lower than present day, so that the river mouth of the Changjiang lay at the shelf edge. As a result, terrigenous materials from the Changjiang and perhaps the Huanghe may have been more easily transported into the middle Okinawa Trough.

The REE compositions of the Unit 1 sediments are more similar to Taiwan-derived sediments than to Changjiang sediments, suggesting that the terrigenous sediments deposited since 7 ka primarily came via transport from Taiwan in the south. Since the middle Holocene at ca. $7 \mathrm{ka}$ when sea level reached a high stand and the main stream of the Kuroshio Current returned to the Okinawa Trough, a large quantity of fine-grained terrigenous particulate matters sourced from Taiwan could have been transported northwards to the middle trough. In contrast, the Changjiang sediment has been restricted to the inner shelf since that time. 
characterized by distinct REE compositions, and are interpreted to be dominated by Japanese volcanic material from the Kikai-Akahoya and Aira-Tanzawa tephras respectively. However, we argue that these volcanic glasses are mixed with fine-grained terrigenous sediments from Taiwan and mainland China respectively.

The provenances of the terrigenous sediments in the middle Okinawa Trough remained stable from the LGM to the middle Holocene, despite large fluctuations of sea level, monsoon activity and depositional environments. Nevertheless, the large variations of depositional fluxes of REE strongly suggest the complex controls of sediments supply rates into the trough during the late Quaternary. In contrast, the erosional effects of the varying monsoon onshore are of secondary importance.

\section{Acknowledgements:}

This work was supported by research funds awarded by the National Natural Science Foundation of China (Grant No. 40676031), the National Basic Research Program of China (2007CB815906), the opening foundation of the Key Laboratory of Marine Sedimentology \& Environmental Geology, SOA (MASEG200605). We thank Z. M. Jian, K. Y. Wei, S. J. Kao and C. F. You for contributive discussions on the original manuscript. Thanks go to Johan Schijf, Gert J. De Lange, and one anonymous reviewer for their constructive comments.

\section{References}

Ahagon, N., Tanaka, Y., Ujiié, H., 1993. Florisphaera profunda, a possible nannoplankton indicator of late Quaternary changes in seawater turbidity at the northwestern margin of the Pacific. Marine Micropaleontology. 22, 255-273.

Arakawa, Y., Kurosawa, M., Takahashi, K., Kobayashi, Y., Tsukui, M., Amakawa, H., 
1998. $\mathrm{Sr}-\mathrm{Nd}$ isotopic and chemical characteristics of the silicic magma reservoir of the Aira pyroclastic eruption, southern Kyushu. Journal of Volcanology and Geothermal Research. 80, 179-194.

Bau M, Dulski, P., 1996. Anthropogenic origin of positive Gadolinium anomalies in river waters. Earth and Planetary Science Letters. 143: 245-255

Chen, L. R., Xu, W. Q., Shen, S. X., 1982. The study on the minerals assemblages and distribution characteristics in the sediment of the East China Sea. Beijng: Science Press, 82-98.

Chen, J. C., Lo, C. Y., Lee, Y. T., Huang, S. W., Chou, P. C., Hu, H. S., Yang, T. F., Wang, Y. S., Chung, S. H., 2007. Mineralogy and chemistry of cored sediments from active margin off southwestern Taiwan. Geochemical Journal. 41, 303-321.

Choi, M. S., Yi, H. I., Yang, S. Y., Lee, C. B., Cha, H. J., 2007. Identification of Pb sources in Yellow Sea sediments using stable $\mathrm{Pb}$ isotope ratios. Marine Chemistry. 107, 255-274.

Clift, P. D., Blusztajn, J., Nguyen, A.D., 2006. Large-scale drainage capture and surface uplift in eastern Tibet-SW China before 24 Ma inferred from sediments of the Hanoi Basin, Vietnam. Geophysical Research Letters. 33, L19403. doi: 10.1029/2006GL027772.

Clift, P. D., Giosan, L., Blusztajn, J., Campbell, I.H., Allen, C.M., Pringle, M., Tabrez, A., Danish, M., Rabbani, M.M., Carter, A., and Lückge, A., 2008, Holocene erosion of the Lesser Himalaya triggered by intensified summer monsoon: Geology. 36, 79-82.

Clift, P. D., Lee, J. I., Blusztajn, J., Clark, M. K., 2002. Erosional response of South China to arc rifting and monsoonal strengthening recorded in the South China Sea. Marine Geology. 184, 207-226. 
Clift, P.D., Schouten, H., and Draut, A.E., 2003, A general model of arc-continent collision and subduction polarity reversal from Taiwan and the Irish Caledonides, in Larter, R.D., and Leat, P.T., eds., Intra-Oceanic Subduction Systems; Tectonic and Magmatic Processes, Volume 219: Special Publication: London, Geological Society. 81-98.

Condie, K. C., 1991. Another look at rare earth elements in shales. Geochimica et Cosmochimica Acta. 55, 2527-2531.

Dadson, S., Hovius, N., Chen, H., Dade, W.B., Hsieh, M.L., Willett, S., Hu, J.C., Horng, M.J., Chen, M.C., Stark, C.P., Lague, D., and Lin, J.C., 2003. Links between erosion, runoff variability and seismicity in the Taiwan Orogen. Nature. 426, 648-651.

Dou, Y. G., Yang, S. Y., Liu, Z. X., Clift, P. D., Yu, H., Berne, S., Shi, X. F., 2010. Clay mineral evolution in the central Okinawa Trough since $28 \mathrm{ka}$ : Implications for sediment provenance and paleoenvironmental change. Palaeogeography Palaeoclimatology Palaeoecology. 288, 108-117.

Emery, K. O., Niino, H., Sullivan, B., 1971. Post-pleistocene levels of the East China Sea. Late Cenozoic Glacial Ages. New Haven: Yale University Press. 381-390.

Guo, Z., Yang, Z., Lei, K., Gao, L., Qu, Y., 2001. The distribution and composition of suspended matters and their influencing factors in the central-southern area of Okinawa Trough and its adjacent shelf sea. Acta Oceanolgica Sinca. 23, 66-72 (in Chinese with English abstract).

Gromet, L. P., Silver, S. T., 1983. Rare earth element distributions among minerals in a granodiorite and their petrogenetic implications. Geochimica et Cosmochimica Acta. 47, 925-939.

Hannigan, R. E., Sholkovitz, E. R., 2001. The development of middle rare earth 
element enrichments in freshwaters: weathering of phosphate minerals. Chemical Geology. 175, 495-508.

526

Hamasaki, S., 2002. Volcanic-related alteration and geochemistry of Iwodake volcano, Satsuma Iwojima, Kyushu, SW Japan. Earth Planets Space. 54, 217-229

Henderson, G. M., 2002. New oceanic proxies for paleoclimate. Earth and Planetary Science Letters. 203, 1-13.

Herzschuh, U., 2006, Palaeo-moisture evolution in monsoonal Central Asia during the last 50,000 years. Quaternary Science Reviews. 25, 163-178.

Honda, M., Kusakabe, M., Nakabayashi, S., 2000. Radiocarbon of sediment trap samples from the Okinawa Trough: lateral transport of ${ }^{14} \mathrm{C}$-poor sediment from the continental slope. Marine Chemistry. 68, 231-247.

Hsu, S. C., Lin, F. J., Jeng, W. L., Chung, Y., Shaw, L. M., Hung, K. W., 2004. Observed sediment fluxes of the southwesternmost Okinawa Trough enhanced by episodic events: flood runoff from northeastern Taiwan river and great earthquakes. Deep-Sea Research (I). 51, 979-997.

Hu, D., Pang, C., Bai, H., Wang, F., 2001. Transportation and budget of particulate materials in the East China Sea. In: Hu, D., Han, W., Zhang, S., et al. (Eds.), Land-sea Interactions in Changjiang and Zhujiang Estuaries and Adjacent Waters. Ocean Press, Beijing. ISBN:7-5027-4513-0, pp. 57-66 (in Chinese with English abstract).

Huh, C. A., Su, C. C., 1999. Sedimentation dynamics in the East China Sea elucidated from ${ }^{210} \mathrm{~Pb},{ }^{137} \mathrm{Cs}$ and ${ }^{239,240} \mathrm{Pu}$. Marine Geology. 160, 183-196.

Huh, C. A., Su, C. C., Liang, W. T., Ling, C. Y., 2004. Linkages between turbidites in the southern Okinawa Trough and submarine earthquakes. Geophysical Research Letters. 31(L12304). doi:10.1029/2004GL019731. 
Hung, J. J., Lin, C. S., Huang, G. W., Chung, Y. C., 1999. Later transport of lithogenic particles from the continental margin of the southern East China Sea. Estuarine Coastal and Shelf Science. 49, 483-499.

Irino, T., and Tada, R., 2002. High-resolution reconstruction of variation in Aeolian dust (Kosa) deposition at ODP Site 797, the Japan Sea, during the last $200 \mathrm{ka}$ : Global and Planetary Change. 35, 143-156.

Iseki, K., Okamura, K., Kiyomoto, Y., 2003. Seasonality and composition of downward particulate fluxes at the continental shelf and Okinawa Trough in the East China Sea. Deep-Sea Research (II). 50, 457-473.

Jeng, W. L., Lin, S., Kao, S. J., 2003. Distribution of terrigenous lipids in marine sediments off northeastern Taiwan. Deep-Sea Research (II). 50, 1179-1201.

Jian, Z., Saito, Y., Wang, P., Li, B., Chen, R., 1998. Shift of the Kuroshio axis over the last 20000 years. Chinese Science Bulletin. 43 (5), 532-536.

Jian, Z., Wang, P., Saito, Y., Wang, J., Pflaumann, U., Oba, T., Cheng, X., 2000. Holocene variability of the Kuroshio Current in the Okinawa Trough, northern Pacific Ocean. Earth and Planetary Science Letters. 184, 305-319.

Katayama, H., Watanabe, Y., 2003. The Huanghe and Changjiang contribution to seasonal variability in terrigenous particulate load to the Okinawa Trough. Deep-Sea Research (II). 50, 475-485.

Kitagawa, H., Fukusawa, H., Nakamura, T., 1995. $\mathrm{AMS}^{14} \mathrm{C}$ dating of varved sediments from Lake Suigetsu, central Japan and atmospheric ${ }^{14} \mathrm{C}$ change during the late Pleistocene. Radiocarbon. 37, 371-378.

Lee, S. Y., Huh, C. A., Su, C. C., You, C. F., 2004. Sedimentation in the Southern Okinawa Trough: enhanced particle scavenging and teleconnection between the Equatorial Pacific and western Pacific margins. Deep-Sea Research (I). 51, 
Li, C. X., Zhang, G. J., 1995. A sea-running changjiang river during the last glaciations ? Acta Geographica Sinica. 50, 459-463 (in Chinese with English abstract).

Liu, J., Zhu, R. X., Li, T. G., Li, A. C., Li, J., 2007. Sediment-magnetic signature of the mid-Holocene paleoenvironmental change in the central Okinawa Trough. Marine Geology. 239, 19-31.

Liu, J. P., Xu, K. H., Li, A. C., Milliman, J.D., Chiu, J.K., Kao, S.J., Lin, S.W., 2008. Flux and fate of small mountainous rivers derived sediments into the Taiwan Strait. Marine Geology. 256, 65-76.

Liu, J. P., Xu, K. H., Li, A. C., Milliman, J. D., Velozzi, D. M., Xiao, S. B., Yang, Z. S., 2007. Flux and fate of Yangtze River sediment delivered to the East China Sea. Geomorphology. 85, 208-224.

Liu, N., Meng, X. W., 2004. Characteristics of rare earth elements in surface sediments from the middle Okinawa Trough: implications for provenance of mixed sediments. Marine Geology and Quaternary Geology. 24, 37-43. (in Chinese with English abstract).

Liu, Y. G., 2005. Estimation of the provenance and flux of the sediments in the Okinawa Trough using quantitative analysis since late 40 ka. Qingdao: Ocean University of China. 112-125 (in Chinese with English abstract).

Liu, Z. X., Berné, S., Saito, Y., 2000. Quaternary seismic stratigraphy and paleoenvironments on the continental shelf of the East China Sea. Journal of Asian Earth Sciences. 18, 441-452.

Liu, Z. X., Li, T. G., Li, P. Y., Huang, Q. Y., Berne, S., Saito,Y., 2001. The paleoclimatic events and cause in the Okinawa Trough during $50 \mathrm{ka}$ BP. Chinese 
600

601

602

603

604

605

606

607

608

609

610

611

612

Liu, Z. X., Saito, Y., Li, T. G., Berne, S., Cheng, Z. B., Li, P. Y., Li, Z., Guichard, F., Floch, G., 1999. Study on millenium-scale paleoceanography in the Okinawa Trough during the late Quaternary. Chinese Science Bulletin. 44(18), 1705-1709.

Machida, H., 1999. The stratigraphy, chronology and distribution of distal marker-tephras in and around Japan. Global and Planetary Change. 21, 71-79.

McLennan, S. M., 1989. Rare earth elements in sedimentary rocks: Influence of provenance and sedimentary processes, in: B.R. Lipin, G.A. McKay (Eds.), Geochemistry and Mineralogy of Rare Earth Elements, Rev. Mineral. 21, $169-200$.

Meng, X. W., Du, D. W., Liu, Y. G., Han, Y. B., 2007. Terrestrial flux in sediments from the Okinawa Trough and its response to climate changes over the past 35 000 a. Acta Oceanologica Sinica. 29, 74-80 (in Chinese with English abstract).

Milliman, J. D., Qin, Y. S., Park, Y. A., 1989. Sediments and sedimentary processes in the Yellow and East China Seas. In: Taira A, Masuda F, eds. Sedimentary Facies in the Active Plate Margin. Tokyo: Terra Scientific Publishing Company. 233-249.

Milliman, J. D., Syvitski, J. P. M., 1992. Geomorphic/tectonic control of sediment discharge to the ocean: The importance of small mountainous rivers. Journal of Geology. 100, 525-544.

Miyairi, Y., Yoshida, K., Miyazaki, Y., et al., 2004. Improved ${ }^{14} \mathrm{C}$ dating of a tephra layer (AT tephra, Japan) using AMS on selected organic fractions. Nuclear Instruments and Methods in Physics Research. B 223-224, 555-559.

Nagashima, K., Tada, R., Matsui, H., Irino, T., Tani, A., Toyoda, S., 2007. Orbital- and millennial-scale variations in Asian dust transport path to the Japan Sea. 
625

626

627

Oguri, K., Matsumoto, E., Yamada, M., 2003. Sediment accumulation rates and budgets of depositing particles of the East China Sea. Deep Sea Research (II). 50, $513-528$.

Qin, Y. S., Zhao, Y. Y., Chen, L. R., 1987. Geology of East China Sea. Beijing, Science Press (in Chinese with English abstract). 1 287.

Saito, Y., Katayama, H., Ikehara, K., 1998. Transgressive and highstand systems tracts and post-glacial transgression, the East China Sea. Sedimentary Geology. 122, 217-232.

Shinjo, R., Kato, Y., 2000. Geochemical constraints on the origin of bimodal magmatism at the Okinawa Trough, an incipient back-arc basin. Lithos. 54, $118-137$.

Song, Y. H., Choi, M. S., 2009. REE geochemistry of fine-grained sediments from major rivers around the Yellow Sea. Chemical Geology. 266: 328-342.

Sun, Y. B., Gao, S., Li, J., 2003. Preliminary analysis of grain-size populations with environmentally sensitive terrigenous components in marginal sea setting. Chinese Science Bulletin. 48, 184-187.

Taylor, S. R., McLennan, S. M., 1985. The Continental Crust: Its Composition and Evolution. Blackwell, Oxford. 1-190.

Tsunogai, S., Suzuki, T., Kurata, T., Uematsu, M., 1985. Seasonal and areal variation of continental aerosol in the surface air over the western North Pacific region. Jounal of Oceanography. 41, 427-434.

Ujiié, H., Hatakeyama, Y., Gu, X. X., 2001. Upward decrease of organic C/N ratios in the Okinawa Trough cores: proxy for tracing the post-glacial retreat of the continental shore line. Plaeogeography, Palaeoclimatology, Palaeoecology. 165, 
650

651

652

653

654

655

656

657

658

659

660

661

662

663

664

665

666

667

668

669

670

671

672

673

Ujiié, H., Tanaka, Y., Ono, T., 1991. Late Quaternary paleoceanographic record from the middle Ryukyu Trench slope, Northwest Pacific. Marine Micropaleontology. $18,115-128$.

Ujiié, H., Ujiié, Y., 1999. Late Quaternary course change of Kuroshio Current in the Ryukyu Arc region, Northwestern Pacific Ocean. Marine Micropaleontology. 37, 23-40.

Vital, H., Stattegger, K., Garbe-Schonberg, C. D., 1999. Composition and trace-element geochemistry of detrital clay and heavy-mineral suites of the lowermost Amazon River: A provenance study. Journal Sedimentary Research. $69,563-575$.

Wang, Y.J., Cheng, H., Edwards, R.L., An, Z.S., Wu, J.Y., Shen, C.-C., and Dorale, J.A., 2001, A high-resolution absolute-dated late Pleistocene Monsoon record from Hulu Cave, China. Science. 294, 2345-2348.

Xiang, R., Li, T., Yang, Z., Li, A., Jiang, F., Yan, J., Cao, Q., 2003. Geological records of marine environmental changes in the southern Okinawa Trough. Chinese Science Bulletin. 48, 194-199.

Xu, X. D., Oda, M., 1999. Surface-water evolution of the eastern East China Sea during the last 36,000 years. Marine Geology. 156, 285-304.

Yan, Y., Xia, B., Lin, G., Carter, A., Hu, X. Q., Cui, X.J., Liu, B. M., Yan, P., Song, Z. J., 2007. Geochemical and Nd isotope composition of detrital sediments on the north margin of the South China Sea: provenance and tectonic implications. Sedimentology. 54, 1-17.

Yang, S. Y., Jung, H. S., Choi, M. S., 2002. The rare earth element compositions of the Changjiang (Yangtze) and Huanghe (Yellow) river sediments. Earth and 
675 Yang, S. Y., Jung, H. S., Li, C. X., 2004. Two unique weathering regimes in the 676 Changjiang and Huanghe drainage basins: geochemical evidence from river 677 sediments. Sedimentary Geology. 164, 19-34.

678 Yang, S.Y., Li, C. X., Cai, J. G., 2006. Geochemical compositions of core sediments in 679 eastern China: Implication for Late Cenozoic palaeoenvironmental changes. 680 Palaeogeography Palaeoclimatology Palaeoecology. 229, 287-302

681 Yang, S. Y., Yim, W. W-S., Huang, G. Q., 2008. Geochemical composition of inner 682 shelf Quaternary sediments in the northern South China Sea with implications for 683 provenance discrimination and paleoenvironmental reconstruction. Global and $684 \quad$ Planetary Change 60, 207-221.

685 Yoo, D. G., Lee, C. W., Kim, S. P., 2002. Late Quaternary transgressive and highstand 686 systems tracts in the northern East China Sea mid-shelf. Marine Geology 187, 687 313-328.

Yu, H., Xiong, Y. Q., Liu, Z. X., Berne, S., Huang, C. Y., Jia, G. D., 2008. Evidence for the 8,200 a B.P. cooling event in the middle Okinawa Trough. Geo-Marine Letters. 28, 131-136.

Yu, H., Liu, Z.X., Berné, S., Jia, G.D., Xiong, Y.Q., Dickens, G.R., Wei, G.J., Shi, X.F., Liu, J.P.,Chen, F.J., 2009. Variations in temperature and salinity of the surface water above the central Okinawa Trough during the past 37 kyr. Palaeogeography Palaeoclimatology Palaeoecology. 281, 154-164.

Zhai, S. K., Xu, S. M., Yu, Z. H., Qin, Y. S., Zhao, Y. Y., 2001. Two possible hydrothermal vents in the northern Okinawa Trough. Chinese Science Bulletin.

698 Zhao Y. Y., Yan M. C., 1992. Abundance of chemical elements in sediments from the 

Huanghe River, the Changjiang River and the Continental Shelf of China. Chinese Science Bulletin. 37, 1991-1994.

701 Zhao, Y. Y., Wang, J. T., Qin, Z. Y., 1990. Rare earth elements in continental shelf 702 sediment of the China Seas. Acta Sedimentologica Sinica. 8, 37-43 (in Chinese with English abstract).

704 
Figure captions:

706

707

Fig. 1

Schematic map showing the locations of Core DGKS9604 and other reference cores. The regional circulation pattern in the East China Sea and the adjacent areas are sourced from Huh and Su (1999) and Yu et al (2008). YSCC=Yellow Sea Coastal Current; ZFCC=Zhejiang-Fujian Coastal Current; CDW=Changjiang Diluted Water; TWC=Taiwan Warm Current; YSWC=Yellow Sea Warm Current.

\section{Fig. 2}

Depth profiles of mean grain size $(\mathrm{Mz}), \delta^{18} \mathrm{O}$ of foraminifera, $\mathrm{CaCO}_{3}$, and $\mathrm{REE}$ fractionation parameters of Core DGKS9604 sediments. The age model, $\delta^{18} \mathrm{O}$ and grain size data after Yu et al $(2008 ; 2009)$. OIS denotes oxygen isotope stage. The lightly shadowed area indicates two tephra layers, i.e. Kikai-Akahoya (K-Ah) and Aira-Tanzawa (AT) (Kitagawa et al., 1995; Arakawa et al., 1998).

\section{Fig. 3}

UCC-normalized patterns of Core DGKS9604 sediments. The samples of Unit 1 and Unit 2 show similar fractionation patterns, much different from two samples primarily of volcanic origins.

\section{Fig. 4}

Comparisons of REE patterns between the sediments of Core DGKS9604, Changjiang and Huanghe (Yang et al., 2002), and volcanic source materials (Arakawa et al., 1998; Hamasaki, 2002; Liu et al., 2004). 
Fig. 5

731 Discrimination plot of $(\mathrm{Gd} / \mathrm{Yb})_{\mathrm{UCC}}$ vs $(\mathrm{La} / \mathrm{Sm})_{\mathrm{UCC}}$ for the sediments of Core 732 DGKS9604. Values of modern Changjiang and Huanghe riverine sediments (Yang et 733 al., 2002), pumice and lavas samples of Aira pyroclastic eruption (Arakawa et al., 734 1998), volcanic rocks of Okinawa Trough (Shinjo and Kato, 2000), and core 735 sediments of southwestern Taiwan (Chen et al., 2007) are also shown for comparison.

736

$737 \quad$ Fig. 6

738 Schematic diagrams showing the influences of sea level change and oceanic 739 circulation patterns on the terrigenous sediment inputs to the Okinawa Trough and 740 adjoining shelf of the East China Sea during the LGM (a) and the mid-late Holocene 741 (0 ca.7 Cal ka BP; b). The direction of the Kuroshio Current at the LGM is after Ujiié 742 and Ujiié (1999) 
1 Provenance discrimination of siliciclastic sediments in the

2 middle Okinawa Trough since $30 \mathrm{ka}$ : Constraints from rare earth

4 Yanguang Dou ${ }^{\mathrm{a}}$, Shouye Yang ${ }^{\mathrm{a}}$, Zhenxia Liu ${ }^{\mathrm{b}}$, Peter D. Clift ${ }^{\mathrm{c}}$, Hua $\mathrm{Yu}^{\mathrm{d}}$,

5 Serge Berne

6
${ }^{a}$ State Key Laboratory of Marine Geology, Tongji University, Shanghai 200092, China

${ }^{\mathrm{b}}$ First Institute of Oceanography, State Oceanic Administration, Qingdao 266071, China

${ }^{\mathrm{c}}$ School of Geosciences, University of Aberdeen, Meston Building, Aberdeen AB24 3UE, United Kingdom

${ }^{\mathrm{d}}$ Department of Earth Sciences, Rice University, Houston, TX 77005, USA

' IFREMER, DRO/GM, P.O. Box 70, 29280 Plouzane', France

Corresponding author:

\section{Shouye Yang}

State Key Laboratory of Marine Geology

Tongji University

Shanghai 200092, China

Tel: 86-21-65989130

Fax: 86-21-6598 6278

E-mail: syyang@tongji.edu.cn 


\section{Abstract:}

The late Quaternary paleoceanography and paleoenvironment in the Okinawa Trough, East China Sea, have been well reconstructed over the last decade, while in contrast the provenance of terrigenous sediments that have accumulated there remains enigmatic. In this study rare earth elements (REE) were used to reveal provenance changes in sediments from Core DGKS9604, taken from the middle Okinawa Trough. Discrimination plots based on REE fractionation parameters suggest that the cored sediments have variable provenances over the last $30 \mathrm{ka}$, with the lower part (ca. 31-8.2 ka) ultimately originating mostly from the Changjiang (Yangtze River) and the upper part (0-7.1 ka) primarily from Taiwan. During the Last Glacial Maximum and early Holocene sea level was low and the main stream of the Kuroshio Current was deflected to the east of the Ryukyu Islands. As a result sediment from the Changjiang dominated sedimentation of the middle Okinawa Trough. However, since about $7 \mathrm{ka}$ the main stream of the Kuroshio Current strengthened in the area of the trough, as sea level reached the modern position. This caused near-bottom transport of fine-grained sediments from the continental margin to the trough to become weak and instead, Taiwan-derived terrigenous sediments dominated in the middle trough. The changing provenances of terrigenous sediments into the middle Okinawa Trough are closely related to the evolution of oceanic circulations and sea level in the East China Sea. Two tephra layers in the core have distinct REE compositions and correlate well with two volcanic eruptions at 7.6 and $25.8 \mathrm{ka}$ in southern Japan.

Keywords: Sediment provenance; the Okinawa Trough; Kuroshio Current; Rare earth element 


\section{Introduction}

The Okinawa Trough is located in the southeast of the East China Sea and is regarded as an incipient intra-continental basin formed behind the Ryukyu arc-trench system (Clift et al., 2003)(Fig. 1). The continuous sedimentation during the late Quaternary in the Okinawa Trough has been regulated by changing terrigenous sediment supply, sea level, oceanic circulation and the intensity of the East Asian monsoon. As a result the sediment source to sink patterns in the Okinawa Trough and adjoining shelf are closely related to these complex controlling factors. In view of this, the Okinawa Trough is an idea natural laboratory in the Western Pacific marginal seas for the studies of later Quaternary land-sea interaction and paleoenvironmental changes.

Over the last two decades, many scientists have attempted to identify the origin of sediment in the middle Okinawa Trough using mineralogical (Chen et al., 1982), oceanographic and paleoceanographic (Jian et al., 1998, 2000; Ujiié and Ujiié, 1999; Liu et al., 1999, 2000), as well as geochemical methods (Zhao and Yan, 1992; Guo et al., 2001; Meng et al., 2001). These studies suggested that the terrigenous sediment sources of the Okinawa Trough predominantly include direct supply from major rivers in East Asia, particularly the Changjiang (Yangtze River) and Huanghe (Yellow River) (Katayama and Watanabe, 2003), and lateral transport from the East China Sea shelf through the bottom layers (Honda et al., 2000; Iseki et al, 2003; Oguri et al., 2003). In particular, during the Last Glacial Maximum (LGM) when the sea level was about $135 \mathrm{~m}$ lower than present-day, Changjiang-derived sediments must have directly emptied into the Okinawa Trough (Milliman et al., 1989; Saito et al., 1998; Yoo et al., 2002; Liu et al., 2007). In addition, the episodic volcanic eruptions in the west Japan 
volcanic zone have produced widespread fallout tephra layers in the northern Okinawa Trough (Machida, 1999; Miyairi et al., 2004). Other factors such as submarine hydrothermal activity (Zeng et al., 2000; Zhai et al., 2001, 2007), erosion of tectonically active Taiwan Island (Liu et al., 2008), eolian transport (Tsunogai et al., 1985), seafloor earthquakes (Huh et al., 2004), as well as intrusion of the Kuroshio Current (Jian et al., 1998; Lee et al., 2004) also contribute to the transport of siliciclastic sediments into and within the trough.

Nevertheless, the origin of sediment in the Okinawa Trough still remains unresolved at present despite many research efforts (Hu et al., 2001; Katayama and Watanabe, 2003). Sedimentation in the middle Okinawa Trough is primarily controlled by Changjiang diluted waters, the Asian winter monsoon winds that originate from northwest of China, as well as the Kuroshio Current, which is derived from the northern equatorial current. Whether the Changjiang (and/or Huanghe) derived particulate materials can directly reach the Okinawa Trough in the present day or during the LGM remains controversial (Li and Zhang, 1995; Xia and Liu, 2001). It has been documented that the terrigenous sediments may have been laterally transported from the East China Sea shelf to the trough after sea level reached its highstand during the mid Holocene (Iseki et al., 2003; Liu et al., 2007). However, the Kuroshio Current strengthened and its main stream returned to the Okinawa Trough at about $7 \mathrm{ka}$ (Jian et al., 2000), which significantly reduced the sediment transport at the bottom from the continental shelf of the East China Sea to the trough because of a “water barrier" effect (Guo et al., 2001).

Whether and how far the terrigenous sediments from Taiwan Island can be transported northward into the middle and north Okinawa Trough is another challenging question waiting for more lines of evidences (Hsu et al., 2004). The 
reliable provenance tracers of terrigenous sediments from different end-members and high-resolution sampling analysis are urgently needed if the sediment transport patterns in and around the Okinawa Trough are to be understood in detail.

Geochemical approaches have been proven to be powerful in identifying sediment provenances in the East Asian marginal seas (Clift et al., 2002, 2006; Yang et al., 2004, 2008; Yan et al., 2007). Among the various methods, rare earth elements (REEs) have been well accepted as reliable provenance tracers because they behave conservatively during sediment formation being largely water-immobile (Taylor and McLennan, 1985; Rollinson, 1993). The main research objectives of this paper are to 1) characterize the REE compositions of sediments from Core DGKS9604 taken from the middle Okinawa Trough; 2) identify the provenance changes of siliciclastic sediments since $30 \mathrm{ka}$; and 3) discuss the competing roles of sea level change, monsoon variability and Kuroshio Current strength and location in regulating the terrigenous sediment inputs into the middle trough.

\section{Samples and methods}

A piston core (DGKS9604) was taken from the middle Okinawa Trough $\left(28^{\circ} 16.64^{\prime} \mathrm{N}, 127^{\circ} 01.43^{\prime} \mathrm{E}\right)$ at a water depth of $766 \mathrm{~m}$ during the joint Chinese-French DONGHAI Cruise in 1996 (Fig. 1). The core is $1076 \mathrm{~cm}$ long and located on the western continental slope of the middle Okinawa Trough. In contrast to the adjacent core DGKS9603 $\left(28^{\circ} 08.869^{\prime} \mathrm{N}, 127^{\circ} 16.238^{\prime} \mathrm{E}\right)$, which was taken during the same cruise (Fig.1), no visual ash layers and hiatuses are present in Core DGKS9604 (Yu, 2006). A high-resolution age model of the core was established on the basis of the oxygen isotopic compositions of Globigerinoides sacculifer and accelerator mass spectrometry (AMS) radiocarbon dating of planktonic foraminifera (Liu et al., 2001; 
Yu et al., 2008). The depositional age at the bottom of the core is estimated to be 37.01 Cal ka, and the bulk sedimentation rate of the core averages about $29 \mathrm{~cm} / \mathrm{k} . \mathrm{y}$, which is higher than that of Core DGKS9603 (Liu et al, 1999, 2000). Sediments from Core DGKS9604 are primarily composed of clayey silt, with a mean grain size of 6.7 $\pm 0.4 \Phi($ Yu, et al, 2008; Fig. 2).

A total of 106 subsamples were collected from Core DGKS9604 at $4 \mathrm{~cm}$ intervals for the uppermost $100 \mathrm{~cm}$ and at $8 \mathrm{~cm}$ intervals between 100 and $743 \mathrm{~cm}$. To separate the residual fractions from the bulk samples, $0.2 \mathrm{~g}$ bulk sediment samples were leached with $20 \mathrm{ml} 1 \mathrm{~N} \mathrm{HCl}$ for 24 hours at $50^{\circ} \mathrm{C}$. The residues of the leached samples were then completely digested with concentrated $\mathrm{HF}-\mathrm{HNO}_{3}-\mathrm{HClO}_{4}$ in an airtight Teflon container. Concentrations of REEs and other elements in the residual fractions were determined by ICP-MS (PQ3, Thermo Elemental) and ICP-AES (IRIS Advantage) in the State Key Laboratory of Marine Geology at Tongji University. The precision and accuracy were monitored by geostandard GSR-5, GSR-6, and GSR-9. Differences between the determined and certified values were less than 5\%, and the leaching efficiency checked by GSR-5, GSR-6, and GSR-9 was above 90\%.

\section{Results and discussions}

\subsection{REE compositions of the Core DGKS9604 sediments}

The average rare earth element compositions of the Core DGKS9604 sediments and the reference materials are given in Table 1. Depth profiles of total REE concentrations, $\mathrm{REE}$ fractionation parameters, $\mathrm{CaCO}_{3}$ contents and mean grain size are shown in Figure 2. The REE compositions, including total REE concentrations, $(\mathrm{La} / \mathrm{Yb})_{\mathrm{ucc}},(\mathrm{La} / \mathrm{Sm})_{\mathrm{ucc}},(\mathrm{Gd} / \mathrm{Yb})_{\mathrm{ucc}}, \delta \mathrm{Ce}(\mathrm{Eu}$ anomalies) and $\delta \mathrm{Eu}(\mathrm{Ce}$ anomalies $)$, exhibit regular variations in the core with a remarkable and abrupt change occurring 
in the mid-Holocene (8.2-7.1 ka) (Fig. 2). The younger sediments (Unit 1, 0-142 cm and deposited since $7.1 \mathrm{ka}$ ) are significantly enriched in REE concentrations and characterized by lower values of $(\mathrm{La} / \mathrm{Yb})_{\mathrm{ucc}},(\mathrm{La} / \mathrm{Sm})_{\mathrm{ucc}}, \delta \mathrm{Ce}$ and $\delta \mathrm{Eu}$ compared to the underlying sediments (Unit 2, 158-743 cm, deposited during 8.2-30.3 ka). However, $(\mathrm{Gd} / \mathrm{Yb})_{\mathrm{ucc}}$ ratios, are relatively higher in Unit 1 than in Unit 2 . In contrast to the REE compositions, the oxygen isotopic values $\left(\delta^{18} \mathrm{O}\right)$ of foraminifera, $\mathrm{CaCO}_{3}$ contents and mean grain size of the sediments show large variations at the boundary between oxygen isotope stages (OIS) 1 and 2 at about $10 \mathrm{ka}$ (Fig. 2), yet this change does not affect the source of the siliciclastic component.

The upper continental crust (UCC)-normalized (Taylor and McLennan, 1985) REE patterns of Core DGKS9604 sediments show relative enrichments in total REE and light REEs (LREE) compared to UCC (Table 1), but also exhibit different forms between the two depositional units. Unit 1 shows remarkable fractionations of middle and heavy REEs with obvious convex shapes in the REE plots, whereas Unit 2 is characterized by relatively flat REE patterns, with no obvious $\mathrm{Ce}$ and $\mathrm{Eu}$ anomalies (Fig. 3).

Two layers with much lower than normal values of $(\mathrm{La} / \mathrm{Yb})_{\mathrm{ucc}},(\mathrm{La} / \mathrm{Sm})_{\mathrm{ucc}}$ and $(\mathrm{Gd} / \mathrm{Yb})_{\mathrm{ucc}}$ occur at core depths of $150 \mathrm{~cm}$ and $575 \mathrm{~cm}$ respectively (Fig. 2). The AMS ${ }^{14} \mathrm{C}$ ages of these two layers are about $7.6 \mathrm{ka}$ and $25.8 \mathrm{ka}$ respectively, which corresponds well with volcanic eruption events documented in southwestern Japan (Kitagawa et al., 1995; Arakawa et al., 1998).

\subsection{Controlling factors of REE compositions in the core sediments}

Many factors, including the bed rock composition in the source area, sediment grain size, mineralogy, intensity of chemical weathering, diagenesis and 
anthropogenic activity are responsible for REE compositions in sediments. Among these competing processes, sediment provenance is regarded as the most important control over REE compositions (Taylor and McLennan, 1985; Condie, 1991; Yang et al., 2002), at least in the case of the present study. It has been well documented that REE are generally enriched in clay and silt fractions, but depleted in sand fractions, because of dilution by quartz and carbonate minerals (McLennan, 1989; Vital and Stattegger, 1999). The Core DGKS9604 sediments are primarily composed of clayey silt with an average grain size ranging from $7.2 \Phi$ to $6.3 \Phi$ (Yu et al., 2006). Poor correlations are observed between mean grain size, REE concentrations and fractionation parameters (Fig. 2), suggesting that the sediment grain size is not an important factor for controlling the REE concentrations in the sediments we analyzed from the middle Okinawa Trough.

In this study, $1 \mathrm{~N} \mathrm{HCl}$ was used to leach the bulk sediment samples and the residual fractions were analyzed for REE concentrations. Therefore, we infer that a major part of the mobile fraction, including carbonate, apatite, Fe-Mn oxides and organic-bound phases were removed from the bulk core sediments (Yang et al., 2002; 2006), and thus that the measured REE compositions overall represent the contributions of the siliciclastic fraction to the sediments. Chemical weathering thus exerts a weak influence on the REE compositions in the residual fractions.

Heavy minerals such as zircon, monazite, garnet, allanite and sphene, despite their low abundances in sediments, may account for a considerable fraction of the bulk REE concentrations because of the high REE concentrations in these minerals (Gromet and Silver, 1983; Tayor and McLennan, 1985; McLennan, 1989; Hannigan and Sholkovitz, 2001). However, recent study suggested that major rock-forming and heavy minerals in total contribute less than $20 \%$ of the total REE concentrations in the 
modern Changjiang riverine sediments (Yang et al., 2002). The mean sediment grain size of Core DGKS9604 ranges from $7.2 \Phi$ to $6.3 \Phi$, smaller than that of the Changjiang sediment $(6.3 \pm 0.4 \Phi)$, which suggests that heavy minerals are probably not the primary control on REE compositions in the core sediments. Consequently, variations of REE concentrations, as well as fractionation patterns in the siliciclastic sediments, should reflect the bulk mineralogy and so clearly indicate changes of sediment provenance.

\subsection{Provenance discrimination of the Core DGKS9604 sediments}

Because of the lower contents of biogenic (opals, radiolarians and diatoms) and authigenic components (Fe-Mn oxides) in the Okinawa Trough (Liu, 2005), the residues of $1 \mathrm{~N} \mathrm{HCl}$ leached samples studied in this paper are primarily composed of detrital silicate minerals, which mainly originated from erosion of terrigenous and volcanic sources. The potential provenances of siliciclastic sediments in the middle Okinawa Trough include terrigenous sources supplied via fluvial and eolian inputs, volcanic and hydrothermal activities, and those carried by the oceanic currents such as the Kuroshio Current from the southern Okinawa Trough. It has long been recognized that the terrigenous flux into the middle and north Okinawa Trough is mainly derived from the shelf of the East China Sea where the sediments predominantly originate from the two largest rivers in China, i.e. Changjiang and Huanghe Rivers (Qin et al., 1987; Iseki et al., 2003; Katayama and Watanabe, 2003; Liu et al., 2007). Further south however Taiwan dominates because it is one of the greatest producers of sediment to the ocean known globally (Milliman and Syvitski, 1992).

Compared to the surface seafloor sediments in the East China Sea, Core DGKS9604 sediments have higher REE concentrations, ratios of $(\mathrm{La} / \mathrm{Yb})_{\mathrm{ucc}}$ and 
$(\mathrm{La} / \mathrm{Sm})_{\mathrm{ucc}}$, and lower of $(\mathrm{Gd} / \mathrm{Yb})_{\mathrm{ucc}}$ (Table 1). Nevertheless, a detailed comparison of REE composition between the sediments from the continental shelf of the East China Sea and from the Core DGKS9604 can not be made because of inadequate data from the East China Sea and different sample pre-treatment methods. Significant differences in REE concentrations and fractionation patterns between Unit 1 and Unit 2 suggest that both depositional units may have different sediment provenances. Unit 2 sediments have REE compositions that are more similar with the modern Changiiang, rather than Huanghe sediments, in terms of their REE concentrations and fractionation parameters (Table 1, Fig 4a). In contrast, Unit 1 sediments have much higher total REE concentrations and different REE fractionation patterns compared to Unit 2 (Table 1; Figs. 2-4). In this study, a discrimination plot of (La/Sm) ucc vs. $(\mathrm{Gd} / \mathrm{Yb})_{\text {ucc }}$ was used to identify the provenance of sediment in Core DGKS9604 (Fig. 5). The figure clearly demonstrates that the Unit 2 sediments plot together with terrigenous detritus (Machida, 1999). Several tephra layers occurring in the sediments of the north Okinawa Trough are mainly composed of volcanic glasses and pumices 
7.6 ka and 25.8 ka have extraordinarily strong HREE enrichment and LREE depletion (Figs. 3, 4), very similar to the surrounding volcanic materials which came from the Kyushu islands of Southwestern Japan (Fig. 1) (Arakawa et al., 1998; Hamasaki, 2002), but much different from the riverine sediments of the Changjiang and Huanghe. This clearly suggests that these two abnormal layers in the Core DGKS9604 predominantly consist of volcanic materials. Two volcanic events, known as Kikai-Akahoya (K-Ah) and Aira-Tanzawa (AT), with eruption ages at 7324 Cal yr BP (Kitagawa et al., 1995) and 25,120 \pm 270 Cal yr BP respectively (Miyairi et al., 2004), are known from southwest Japan (Fig. 1). They were regarded as the origin of two widely-distributed tephra layers in the sediments of the middle and north Okinawa Trough, which predominantly consist of volcanic glasses and pumices (Xu et al., 1999; Liu et al., 2000; Ujiie et al., 2001; Sun et al., 2003). The two geochemically abnormal layers in the Core DGKS9604 are thus estimated to be dominated by K-Ah tephra and AT tephra, especially considering that they have similar ages.

The average REE concentrations of the volcanic glass (Liu et al., 2004) and volcanic rocks around the southwestern Japan Island (Shinjo and Kato, 2000) are 93.7 ug/g and $109.6 \mathrm{ug} / \mathrm{g}$ respectively, much lower than those found in this core, or in sediments from the Changjiang and Huanghe Rivers (Table 1). Indeed, the total REE concentrations of these two layers are $174.0 \mathrm{ug} / \mathrm{g}$ and $129.0 \mathrm{ug} / \mathrm{g}$ respectively, much higher than those of the documented volcanic materials, which implies that these two tephra layers are probably mixed with other terrigenous sediments, which have higher REE concentrations. The discrimination plot suggests that the abnormal layer 1 deposited at $7.6 \mathrm{ka}$ was probably mixed by the K-Ah tephra with fine-grained sediments from Taiwan, while abnormal layer 2, which was deposited at 25.8 ka was formed by mixture between the AT tephra and riverine sediments from mainland 
China (Fig. 5).

3.4 Transport pattern of detrital sediments into the middle Okinawa Trough during the last $30 \mathrm{ka}$

The identification of sediment sources in the Okinawa Trough is of great significance for understanding the depositional history and paleoenvironmental changes of the East China Sea during the late Quaternary. REE concentrations and fractionation patterns strongly suggest that the siliciclastic sediments accumulated in the middle Okinawa Trough during the late Quaternary might originate from different provenances. During the period from late last glaciation (30 ka) to the early-middle Holocene $(8.0 \sim 7.0 \mathrm{ka})$ the Changjiang was the primary sediment supplier, whereas during the mid-late Holocene of the last 7 ka Taiwan could be the dominant sediment supplier.

The lowest sea level during the Last Glacial Maximum (LGM) was about 135 m lower than that of today (Emery et al., 1971; Qin et al., 1987; Henderson, 2002), which implies that the continental shelf of the East China Sea would have been largely exposed and correspondingly, that the river mouths of the paleo-Changjiang and/or paleo-Huanghe must have been positioned significantly closer to present-day's outer shelf (Fig. 6a). Furthermore, the main stream of the Kuroshio Current deflected to the east of the Ryukyu Islands Arc during the LGM (Ujiie et al., 1991; Ahagon et al., 1993; Xiang et al., 2003) (Fig. 6a). As a result, the terrigenous fine-grained particulate materials from the Changjiang and/or Huanghe might have been transported directly into the middle Okinawa Trough and dominated the deposition there, since there would have been no influence from the Kuroshio Current. 
China into the East Asian marginal seas increased during the LGM (Irino and Tada, 2002; Nagashima et al., 2007). It is well known that the Huanghe sediments have very similar REE compositions with the loess because the latter is the main sediment provenance of the Huanghe (Yang et al., 2002). The Unit 2 and Huanghe sediments plot in different groups in the discrimination plot (Fig. 5), suggesting that the Huanghe-derived and eolian materials did not contribute significantly to the siliciclastic deposition in the middle Okinawa Trough during the LGM.

During the deglacial period and early Holocene, the Changjiang river mouth retreated with the postglacial sea-level rising to its present position at about $7 \mathrm{ka}$ (Liu et al., 2007). The main stream of the Kuroshio Current re-entered the Okinawa Trough and/or strengthened at about 7.5-6.0 ka (Ujiie et al., 1991; Jian et al., 1998, 2000; Xiang et al., 2003). Since then, sedimentation in the Okinawa Trough has been dominated by the competing processes of the Kuroshio Current and the oceanic circulations in the East China Sea (Yang et al., 1992; Lee et al., 2004). Sediment trap experiments revealed that a significant amount of suspended terrigenous particles are transported through the bottom layer from the outer shelf of the East China Sea to the Okinawa Trough (Iseki et al., 2003; Katayama and Watanabe, 2003; Pang and Wang, 2004). Near-bottom transport may be a key process for shelf-to-deep sea export of biogenic/lithogenic particles (Iseki et al., 2003).

The REE compositions of the Unit 1 sediments are remarkably different from the Unit 2 and riverine sediments from mainland China, but very similar with those of Taiwan-derived sediments (Table 1; Figs. 2 and 5). This implies that the siliciclastic sediments deposited since $7 \mathrm{ka}$ in the middle Okinawa Trough were primarily sourced from Taiwan, and probably transported northward by the main stream of the Kuroshio Current, after their initial deposition from the Lanyang River delta and fan. In contrast, 
the sediment transport through the bottom layer from the outer shelf of the East China Sea to the middle Okinawa Trough during the mid-late Holocene was relatively weak as a result of the blocking effect of the Kuroshio and Taiwan Warm Currents, which act as a barrier deflecting other currents from the area (Fig. 6b). Therefore, the suspended or resuspended fine-grained sediments of the Changjiang and/or Huanghe would not have been able to dominate the sedimentation in the middle Okinawa Trough since the high stand of sea level at ca. $7 \mathrm{ka}$.

The basins offshore northeastern Taiwan experience an extremely energetic sediment transport regime due to the passage of the Kuroshio Current and its interaction with the high rugged bathymetry in the southern trough. Annual loading of riverine suspended particulate matter from northern Taiwan (ca. $2 \times 10^{7}$ ton $^{\mathrm{yr}^{-1}}$ ) makes the island an important source for sediments to the subduction margin accretionary wedge (Hung et al., 1999; Dadson et al., 2003). The sediments in the Southern Okinawa Trough has been suggested to be primarily derived from the Lanyang River in northern Taiwan and other eastern Taiwanese rivers, transported by the Kuroshio Current (Hsu et al., 2004; Jian et al., 2000; Jeng et al., 2003; Huh et al., 2004; Lee et al., 2004).

It is interesting to note that the REE compositions of Core DGKS9604 sediments do not vary simultaneously with the oxygen isotopes of foraminifera or with bulk $\mathrm{CaCO}_{3}$ compositions, which show abrupt and large variations at ca. 10 ka (Figs. 2). For example, the oxygen isotope of foraminifera and bulk $\mathrm{CaCO}_{3}$ show heavier and lower values respectively during the LGM than in the Holocene (Fig. 2) (Jian et al., 2000; Liu et al., 2001). The relatively uniform REE compositions of the Unit 2 sediments suggest that from ca. 30 to $7.0 \mathrm{ka}$ the provenances of the terrigenous sediments of the middle Okinawa Trough remained stable, despite large fluctuations 
of sea level, monsoon activity and depositional environments as well. In comparison, the oxygen isotope of foraminifera and bulk $\mathrm{CaCO}_{3}$ compositions in the core sediments that reflect the in-situ paleoenvironment and primary productivity are more sensitive to changing sea level, depositional environments and/or monsoon activity during the late Quaternary. The depositional flux of REE to the Core DGKS9604 sediments varied significantly since $30 \mathrm{ka}$, shown by higher fluxes at 30-22, 17.8-11.8, 6-4, and 2-0 ka and were lower at 22-17.8, 11.8-6.0, 4-2 ka (Fig. 2). The variable depositional fluxes of REE strongly suggests that the changing supply rates of terrigenous sediments into the middle Okinawa Trough during the late Quaternary, core location, most notably the distance of the river mouth from the middle Okinawa Trough and transport processes of fine-grained sediments in the continental margin will not considered in greater detail in this paper.

\section{Conclusions}


One hundred and six sub-samples of Core DGKS9604, which spans the past 30

k.y. and comprises clayey silt, were collected from the middle Okinawa Trough for sediment provenance study. Based on REE geochemical characteristics of the residual fractions leached by $1 \mathrm{~N} \mathrm{HCl}$, we conclude that Core DGKS9604 can be divided into an upper Unit $1(0-142 \mathrm{~cm},<7.1 \mathrm{ka})$ and Unit $2(158-743 \mathrm{~cm}, 8.2-30.3 \mathrm{ka})$. Total REE concentrations and fractionation parameters, including $(\mathrm{La} / \mathrm{Yb})_{\mathrm{ucc}},(\mathrm{La} / \mathrm{Sm})_{\mathrm{ucc}}$, $(\mathrm{Gd} / \mathrm{Yb})_{\mathrm{ucc}}, \mathrm{Ce}$ and Eu anomalies, are significantly different between Units 1 and 2, with large and abrupt variations occurring at 8.2-7.1 ka. The UCC-normalized REE patterns of the Unit 2 sediments are very similar compared to those of the riverine sediments from mainland China, especially from the Changjiang. This observation suggests that the terrigenous fine-grained sediments which accumulated in the middle Okinawa Trough from LGM to the middle Holocene might originate predominantly from the Changjiang. During that period, the main stream of the Kuroshio Current was deflected to the east of the Ryukyu Islands and the sea level remained lower than present day, so that the river mouth of the Changjiang lay at the shelf edge. As a result terrigenous materials from the Changjiang and perhaps the Huanghe may have been more easily transported into the middle Okinawa Trough.

The REE compositions of the Unit 1 sediments are more similar to Taiwan-derived sediments than to Changjiang sediments, suggesting that the terrigenous sediments deposited since 7 ka primarily came via transport from Taiwan in the south. Since the middle Holocene when sea level reached a high stand and the main stream of the Kuroshio Current returned to the Okinawa Trough, a large quantity of fine-grained terrigenous particulate matters sourced from Taiwan could have been transported northwards to the middle trough. In contrast, the Changjiang sediment has 
been restricted to the inner shelf since that time.

Two geochemically abnormal layers with depositional ages at 7.6 and $25.8 \mathrm{ka}$ are characterized by distinct REE compositions, and are interpreted to be dominated by Japanese volcanic material from the Kikai-Akahoya and Aira-Tanzawa tephras respectively. However, we argue that these volcanic glasses are mixed with fine-grained terrigenous sediments from mainland China and Taiwan.

The provenances of the terrigenous sediments in the middle Okinawa Trough remained stable from the LGM to the middle Holocene, despite large fluctuations of sea level, monsoon activity and depositional environments. Nevertheless, the large variations of depositional fluxes of REE strongly suggest the complex controls of sediments supply rates into the trough during the late Quaternary. The erosional effects of the varying monsoon onshore are in contrast of secondary importance.

\section{Acknowledgements:}

This work was supported by research funds awarded by the National Natural Science Foundation of China (Grant No. 40676031), the National Basic Research Program of China (2007CB815906), the opening foundation of the Key Laboratory of Marine Sedimentology \& Environmental Geology, SOA (MASEG200605). We thank Z. M. Jian, K. Y. Wei, S. J. Kao and C. F. You for contributive discussions on the original manuscript.

\section{References}

Ahagon, N., Tanaka, Y., Ujiié, H., 1993. Florisphaera profunda, a possible nannoplankton indicator of late Quaternary changes in seawater turbidity at the northwestern margin of the Pacific. Mar. Micropaleontol. 22, 255-273.

Arakawa, Y., Kurosawa, M., Takahashi, K., Kobayashi, Y., Tsukui, M., Amakawa, H., 
1998. Sr-Nd isotopic and chemical characteristics of the silicic magma reservoir of the Aira pyroclastic eruption, southern Kyushu, Japan. J. of Volcanol. and Geothermal Res. 80, 179-194.

Chen, L. R., Xu, W. Q., Shen, S. X., 1982. The study on the minerals assemblages and distribution characteristics in the sediment of the East China Sea. Beijng: Science Press, 82-98.

Chen, J. C., Lo, C. Y., Lee, Y. T., Huang, S. W., Chou, P. C., Hu, H. S., Yang, T. F., Wang, Y. S., Chung, S. H., 2007. Mineralogy and chemistry of cored sediments from active margin off southwestern Taiwan. Geochem. J. 41, 303-321.

Clift, P. D., Blusztajn, J., Nguyen, A.D., 2006. Large-scale drainage capture and surface uplift in eastern Tibet-SW China before 24 Ma inferred from sediments of the Hanoi Basin, Vietnam. Geophys. Res. Lett. 33, L19403. doi: 10.1029/2006GL027772.

Clift, P. D., Giosan, L., Blusztajn, J., Campbell, I.H., Allen, C.M., Pringle, M., Tabrez, A., Danish, M., Rabbani, M.M., Carter, A., and Lückge, A., 2008, Holocene erosion of the Lesser Himalaya triggered by intensified summer monsoon: Geol. $36,79-82$.

Clift, P. D., Lee, J. I., Blusztajn, J., Clark, M. K., 2002. Erosional response of South China to arc rifting and monsoonal strengthening recorded in the South China Sea. Mar. Geol. 184, 207-226.

Clift, P.D., Schouten, H., and Draut, A.E., 2003, A general model of arc-continent collision and subduction polarity reversal from Taiwan and the Irish Caledonides, in Larter, R.D., and Leat, P.T., eds., Intra-Oceanic Subduction Systems; Tectonic and Magmatic Processes, Volume 219: Special Publication: London, Geological Society. 81-98. 
449 Condie, K. C., 1991. Another look at rare earth elements in shales. Geochimiea et $450 \quad$ Cosmochimica Acta. 55, 2527-2531.

451

452

Dadson, S., Hovius, N., Chen, H., Dade, W.B., Hsieh, M.L., Willett, S., Hu, J.C., Horng, M.J., Chen, M.C., Stark, C.P., Lague, D., and Lin, J.C., 2003. Links between erosion, runoff variability and seismicity in the Taiwan orogen: Nature. 426, 648-651.

Emery, K. O., Niino, H., Sullivan, B., 1971. Post-pleistocene levels of the East China Sea. Late Cenozoic Glacial Ages. New Haven: Yale University Press. 381-390.

Guo, F., Yang, Z. S., Liu, Z. X., Guo, Z. G., Fan, D. J., Saito, Y., Berne, S., 2001. Geochemical characteristics of sediments from the middle Okinawa Trough since the latest pleniglacial period and periodic characteristics of its sediment sources. Acta Oceanologica Sinica. 23, 117-126 (in Chinese with English abstract).

Gromet, L. P., Silver, S. T., 1983. Rare earth element distributions among minerals in a granodiorite and their petrogenetic implications, Geochim. Cosmochim. Acta 47, 925-939.

Hannigan, R. E., Sholkovitz, E. R., 2001. The development of middle rare earth element enrichments in freshwaters: weathering of phosphate minerals, Chem. Geol. 175, 495-508.

Hamasaki, S., 2002. Volcanic-related alteration and geochemistry of Iwodake volcano, Satsuma Iwojima, Kyushu, SW Japan. Earth Planets Space 54, 217-229

Henderson, G. M., 2002. New oceanic proxies for paleoclimate. Earth and Planet. Sci. Lett. 203, 1-13.

Herzschuh, U., 2006, Palaeo-moisture evolution in monsoonal Central Asia during the last 50,000 years: Quat. Sci. Rev. 25, 163-178.

Honda, M., Kusakabe, M., Nakabayashi, S., 2000. Radiocarbon of sediment trap 
samples from the Okinawa Trough: lateral transport of ${ }^{14} \mathrm{C}$-poor sediment from the continental slope. Mar. Chem. 68, 231-247.

Hsu, S. C., Lin, F. J., Jeng, W. L., Chung, Y., Shaw, L. M., Hung, K. W., 2004. Observed sediment fluxes of the southwesternmost Okinawa Trough enhanced by episodic events: flood runoff from northeastern Taiwan river and great earthquakes. Deep-Sea Res. (I) 51, 979-997.

Hu, D., Pang, C., Bai, H., Wang, F., 2001. Transportation and budget of particulate materials in the East China Sea. In: Hu, D., Han, W., Zhang, S., et al. (Eds.), Land-sea Interactions in Changjiang and Zhujiang Estuaries and Adjacent Waters. Ocean Press, Beijing. ISBN:7-5027-4513-0, pp. 57-66 (in Chinese with English abstract).

Huh, C. A., Su, C. C., 1999. Sedimentation dynamics in the East China Sea elucidated from ${ }^{210} \mathrm{~Pb},{ }^{137} \mathrm{Cs}$ and ${ }^{239,240} \mathrm{Pu}$. Mar. Geol. 160, 183-196.

Huh, C. A., Su, C. C., Liang, W. T., Ling, C. Y., 2004. Linkages between turbidites in the southern Okinawa Trough and submarine earthquakes. Geophys. Res. Lett. 31(L12304).

Hung, J. J., Lin, C. S., Huang, G. W., Chung, Y. C., 1999. Later transport of lithogenic particles from the continental margin of the southern East China Sea. Est. Coast. and Shelf Sci. 49, 483-499.

Irino, T., and Tada, R., 2002. High-resolution reconstruction of variation in Aeolian dust (Kosa) deposition at ODP Site 797, the Japan Sea, during the last 200 ka: Global and Planet. Change 35, 143-156.

Iseki, K., Okamura, K., Kiyomoto, Y., 2003. Seasonality and composition of downward particulate fluxes at the continental shelf and Okinawa Trough in the East China Sea. Deep-sea Res. (II) 50, 457-473. 
Jeng, W. L., Lin, S., Kao, S. J., 2003. Distribution of terrigenous lipids in marine sediments off northeastern Taiwan. Deep-Sea Res. (II) 50, 1179-1201.

Jian, Z., Saito, Y., Wang, P., Li, B., Chen, R., 1998. Shift of the Kuroshio axis over the last 20000 years. Chin. Sci. Bull. 43 (5), 532-536.

Jian, Z., Wang, P., Saito, Y., Wang, J., Pflaumann, U., Oba, T., Cheng, X., 2000. Holocene variability of the Kuroshio Current in the Okinawa Trough, northern Pacific Ocean. Earth Planet. Sci. Lett. 184, 305-319.

Katayama, H., Watanabe, Y., 2003. The Huanghe and Changjiang contribution to seasonal variability in terrigenous particulate load to the Okinawa Trough. Deep-Sea Res. (II) 50, 475-485.

Kitagawa, H., Fukusawa, H., Nakamura, T., 1995. $\mathrm{AMS}^{14} \mathrm{C}$ dating of varved sediments from Lake Suigetsu, central Japan and atmospheric ${ }^{14} \mathrm{C}$ change during the late Pleistocene. Radiocarbon 37, 371-378.

Lee, S. Y., Huh, C. A., Su, C. C., You, C. F., 2004. Sedimentation in the Southern Okinawa Trough: enhanced particle scavenging and teleconnection between the Equatorial Pacific and western Pacific margins. Deep-Sea Res. (I) 51, $1769-1780$.

Li, C. X., Zhang, G. J., 1995. A sea-running changjiang river during the last glaciation ? Acta Geographica Sinica. 50, 459-463 (in Chinese with English abstract).

Liu, J., Zhu, R. X., Li, T. G., Li, A. C., Li, J., 2007. Sediment-magnetic signature of the mid-Holocene paleoenvironmental change in the central Okinawa Trough. Mar. Geol.239, 19-31.

Liu, J. P., Xu, K. H., Li, A. C., Milliman, J.D., Chiu, J.K., Kao, S.J., Lin, S.W., 2008. Flux and fate of small mountainous rivers derived sediments into the Taiwan 
Liu, J. P., Xu, K. H., Li, A. C., Milliman, J. D., Velozzi, D. M., Xiao, S. B., Yang, Z. S., 2007. Flux and fate of Yangtze River sediment delivered to the East China Sea. Geomorphol. 85, 208-224.

Liu, N., Meng, X. W., 2004. Characteristics of rare earth elements in surface sediments from the middle Okinawa Trough: implications for provenance of mixed sediments. Mar. Geol. and Quat. Geol. 24, 37-43. (in Chinese with English abstract).

Liu, Y. G., 2005. Estimation of the provenance and flux of the sediments in the Okinawa Trough using quantitative analysis since late 40 ka. Qingdao: Ocean University of China, 112-125 (in Chinese with English abstract).

Liu, Z. X., Berné, S., Saito, Y., 2000. Quaternary seismic stratigraphy and paleoenvironments on the continental shelf of the East China Sea. J. of Asian Earth Sci. 18, 441-452.

Liu, Z. X., Li, T. G., Li, P. Y., Huang, Q. Y., Berne, S., Saito,Y., 2001. The paleoclimatic events and cause in the Okinawa Trough during $50 \mathrm{ka}$ BP. Chinese Sci. Bull. 46, 153-157.

Liu, Z. X., Saito, Y., Li, T. G., Berne, S., Cheng, Z. B., Li, P. Y., Li, Z., Guichard, F., Floch, G., 1999. Study on millenium-scale paleoceanography in the Okinawa Trough during the late Quaternary. Chinese Sci. Bull. 44(18), 1705-1709.

Machida, H., 1999. The stratigraphy, chronology and distribution of distal marker-tephras in and around Japan. Global and Planet. Change 21, 71-79.

McLennan, S. M., 1989. Rare earth elements in sedimentary rocks: Influence of provenance and sedimentary processes, in: B.R. Lipin, G.A. McKay (Eds.), Geochemistry and Mineralogy of Rare Earth Elements, Rev. Mineral. 21, 
Meng, X. W., Du, D. W., Liu, Y. G., Han, Y. B., 2007. Terrestrial flux in sediments from the Okinawa Trough and its response to climate changes over the past 35 000 a. Acta Oceanologica Sinica. 29, 74-80 (in Chinese with English abstract).

Meng, X. W., Du, D. W., Wu, J. L., 2001. Quantitative partition of sources of surface sediments from the middle Okinawa Trough into their end members using $\mathrm{Sr}-\mathrm{Nd}$ isotope. Oceanologia et Limnologia Sinica. 32, 319-326 (in Chinese with English abstract).

Milliman, J. D., Qin, Y. S., Park, Y. A., 1989. Sediments and sedimentary processes in the Yellow and East China Seas. In: Taira A, Masuda F, eds. Sedimentary Facies in the Active Plate Margin. Tokyo: Terra Scientific Publishing Company, 233-249.

Milliman, J. D., Syvitski, J. P. M., 1992. Geomorphic/tectonic control of sediment discharge to the ocean: The importance of small mountainous rivers. J. of Geol., $525-544$.

Miyairi, Y., Yoshida, K., Miyazaki, Y., et al., 2004. Improved ${ }^{14} \mathrm{C}$ dating of a tephra layer (AT tephra, Japan) using AMS on selected organic fractions. Nuclear Instruments and Methods in Physics Research 223-224, 555-559.

Nagashima, K., Tada, R., Matsui, H., Irino, T., Tani, A., Toyoda, S., 2007. Orbital- and millennial-scale variations in Asian dust transport path to the Japan Sea. Palaeogeography, Palaeoclimatology, Palaeoecology 247, 144-161.

Oguri, K., Matsumoto, E., Yamada, M., 2003. Sediment accumulation rates and budgets of depositing particles of the East China Sea. Deep sea Res. (II). 50, $513-528$.

Pang, C. G., Wang, F., 2004. The distributing features and temporal variability of 
suspended matter concentration in the East China Sea. Studia Marina Sinica. 46, $22-31$.

Qin, Y. S., Zhao, Y. Y., Chen, L. R., 1987. Geology of East China Sea. Beijing, Science Press (in Chinese with English abstract).

Rollinson, H., 1993. Using Geochemical Data: Evaluation, Presentation, Interpretation. John Willey \& Sons, New York.

Saito, Y., Katayama, H., Ikehara, K., 1998. Transgressive and highstand systems tracts and post-glacial transgression, the East China Sea. Sedi. Geol. 122, 217-232.

Shinjo, R., Kato, Y., 2000. Geochemical constraints on the origin of bimodal magmatism at the Okinawa Trough, an incipient back-arc basin. Lithos. 54, $118-137$.

Sun, Y. B., Gao, S., Li, J., 2003. Preliminary analysis of grain-size populations with environmentally sensitive terrigenous components in marginal sea setting. Chinese Sci. Bull. 48, 184-187.

Taylor, S. R., McLennan, S. M., 1985. The Continental Crust: Its Composition and Evolution. Blackwells, Oxford. 1-190.

Tsunogai, S., Suzuki, T., Kurata, T., Uematsu, M., 1985. Seasonal and areal variation of continental aerosol in the surface air over the western North Pacific region. J. of Oceanog. 41, 427-434.

Ujiié, H., Hatakeyama, Y., Gu, X. X., 2001. Upward decrease of organic C/N ratios in the Okinawa Trough cores: proxy for tracing the post-glacial retreat of the continental shore line. Plaeogeography, Palaeoclimatology, Palaeoecology 165, $129-140$.

Ujiié, H., Tanaka, Y., Ono, T., 1991. Late Quaternary paleoceanographic record from the middle Ryukyu Trench slope, Northwest Pacific. Mar. Micropaleontol. 18, 
600

601

602

603

604

605

606

607

608

609

610

611

612

613

614

615

616

617

Ujiié, H., Ujiié, Y., 1999. Late Quaternary course change of Kuroshio Current in the Ryukyu Arc region, Northwestern Pacific Ocean. Mar. Micropaleontol. 37, 23-40.

Vital, H., Stattegger, K., Garbe-Schonberg, C. D., 1999. Composition and trace-element geochemistry of detrital clay and heavy-mineral suites of the lowermost Amazon River: A provenance study. J. Sediment. Res. 69, 563-575.

Wang, Y.J., Cheng, H., Edwards, R.L., An, Z.S., Wu, J.Y., Shen, C.-C., and Dorale, J.A., 2001, A high-resolution absolute-dated late Pleistocene Monsoon record from Hulu Cave, China. Science 294, 2345-2348.

Xia, D. X., Liu, Z. X., 2001. Tracing the Changjiang River's flowing route entering the sea during the last ice age maximum. Acta Oceanologica Sinca. 23, 87-94. (in Chinese with English abstract)

Xiang, R., Li, T., Yang, Z., Li, A., Jiang, F., Yan, J., Cao, Q., 2003. Geological records of marine environmental changes in the southern Okinawa Trough. Chinese Sci. Bull. 48, 194-199.

Xiong, Y. Q., Liu, Z. X., 2004. Variations in sediment provenance and its implications of Core DGKS9603 since the late Quaternary. Acta Oceanologica Sinica. 26, 61-71 (in Chinese with English abstract).

Xu, X. D., Oda, M., 1999. Surface-water evolution of the eastern East China Sea during the last 36,000 years. Mar. Geol. 156, 285-304.

Yan, Y., Xia, B., Lin, G., Carter, A., Hu, X. Q., Cui, X.J., Liu, B. M., Yan, P., Song, Z. J., 2007. Geochemical and $\mathrm{Nd}$ isotope composition of detrital sediments on the north margin of the South China Sea: provenance and tectonic implications. Sediment. 54, 1-17. 
Yang, S. Y., Jung, H. S., Choi, M. S., 2002. The rare earth element compositions of the Changjiang (Yangtze) and Huanghe (Yellow) river sediments. Earth and Planet. Sci. Lett. 201, 407-419.

Yang, S. Y., Jung, H. S., Li, C. X., 2004. Two unique weathering regimes in the Changjiang and Huanghe drainage basins: geochemical evidence from river sediments. Sedi. Geol. 164, 19-34.

Yang, S.Y., Li, C. X., Cai, J. G., 2006. Geochemical compositions of core sediments in eastern China: Implication for Late Cenozoic palaeoenvironmental changes. Palaeogeography Palaeoclimatology Palaeoecology 229, 287-302

Yang, S. Y., Yim, W. W-S., Huang, G. Q., 2008. Geochemical composition of inner shelf Quaternary sediments in the northern South China Sea with implications for provenance discrimination and paleoenvironmental reconstruction. Global and Planet. Change 60, 207-221.

Yang, Z., Guo, Z.,Wang, Z., Xu, J., Gao,W., 1992. The macro-pattern of eastward transportation of suspended matters from the shelf to the deep sea in the Yellow Sea and the East China Sea. Acta Oceanol. Sin. 14 (2), 81-90. (in Chinese with English abstract).

Yoo, D. G., Lee, C. W., Kim, S. P., 2002. Late Quaternary transgressive and highstand systems tracts in the northern East China Sea mid-shelf. Mar. Geol. 187, $313-328$.

Yu, H., 2006. Paleoclimate and paleoceanography study of the middle Okinawa Trough in the last 37 Cal ka BP. Qingdao: Ocean University of China. 24-95 (in Chinese with English abstract).

Yu, H., Xiong, Y. Q., Liu, Z. X., Berne, S., Huang, C. Y., Jia, G. D., 2008. Evidence for the 8,200 a B.P. cooling event in the middle Okinawa Trough. Geo-Mar. Lett. 
650

651

652

653

654

655

656

657

658

659

660

661

662

663

664

665

666

Zeng, Z., Jiang, F., Zhai, S., Qin, Y., Hou, Z., 2000. Sulfur isotopic composition of seafloor hydrothermal sediment from the Jade hydrothermal field in the central Okinawa Trough and its geological significance. Acta Oceanol. Sin. 22 (4), 74-82 (in Chinese with English abstract).

Zhai, S. K., Xu, S. M., Yu, Z. H., Qin, Y. S., Zhao, Y. Y., 2001. Two possible hydrothermal vents in the northern Okinawa Trough. Chinese Sci. Bull. 46, 943-945.

Zhai, S. K., Yu, Z. H., Du, T. J., 2007. Elemental geochemical records of modern seafloor hydrothermal activities in sediments from the central Okinawa Trough. Acta Oceanologica Sinica. 29, 58-65 (in Chinese with English abstract).

Zhao Y. Y., Yan M. C., 1992. Abundance of chemical elements in sediments from the Huanghe River, the Changjiang River and the Continental Shelf of China. China Sci. Bull. 37, 1991-1994.

Zhao, Y. Y., Wang, J. T., Qin, Z. Y., 1990. Rare earth elements in continental shelf sediment of the China Seas. Acta Sedimentologica Sinica. 8, 37-43 (in Chinese with English abstract). 


\section{Figure captions:}

668 Fig. 1

669 Schematic map showing the locations of Core DGKS9604 and other reference cores.

670 The regional circulation pattern in the East China Sea and the adjacent areas are 671 sourced from Huh and Su (1999) and Yu (2006). YSCC=Yellow Sea Coastal Current; ZFCC=Zhejiang-Fujian Coastal Current; CDW=Changjiang Diluted Water;

673 TWC=Taiwan Warm Current; YSWC=Yellow Sea Warm Current.

$674 \quad$ Fig. 2

675 Depth profiles of mean grain size $(\mathrm{Mz}), \delta^{18} \mathrm{O}$ of foraminifera, $\mathrm{CaCO}_{3}$, and $\mathrm{REE}$ 676 fractionation parameters of Core DGKS9604 sediments. The age model, $\delta^{18} \mathrm{O}$ and 677 grain size data after Yu et al. (2006, 2008). OIS denotes oxygen isotope stage. The 678 lightly shadowed area indicates two tephra layers, i.e. Kikai-Akahoya (K-Ah) and 679 Aira-Tanzawa (AT) (Kitagawa et al., 1995; Arakawa et al., 1998).

$680 \quad$ Fig. 3

681 UCC-normalized patterns of Core DGKS9604 sediments. The samples of Unit 1 and 682 Unit 2 show similar fractionation patterns respectively, much different from two 683 samples primarily of volcanic origins.

$684 \quad$ Fig. 4

685 Comparisons of REE patterns between the sediments of Core DGKS9604, Changjiang 686 and Huanghe (Yang et al., 2002), and volcanic source materials (Arakawa et al., 1998;

687 Hamasaki, 2002; Liu et al., 2004).

688 Fig. 5

689 Discrimination plot of $(\mathrm{Gd} / \mathrm{Yb})_{\mathrm{ucc}}$ vs $(\mathrm{La} / \mathrm{Sm})_{\mathrm{ucc}}$ for the sediments of Core DGKS9604.

690 Values of modern Changjiang and Huanghe riverine sediments (Yang et al, 2002), 691 pumice and lavas samples of Aira pyroclastic eruption (Arakawa et al, 1998), volcanic 
692 rocks of Okinawa Trough (Shinjo and Kato, 2000), and core sediments of 693 southwestern Taiwan (Chen et al., 2007) are also shown for comparison.

694 Fig. 6

695 Schematic diagrams showing the influences of sea level change and oceanic 696 circulation patterns on the terrigenous sediment inputs to the Okinawa Trough and 697 adjoining shelf of the East China Sea during the LGM (a) and the mid-late Holocene 698 (0 ca.7 Cal ka BP; b). The direction of the Kuroshio Current at the LGM is after Ujiié 699 and Ujiié (1999). 


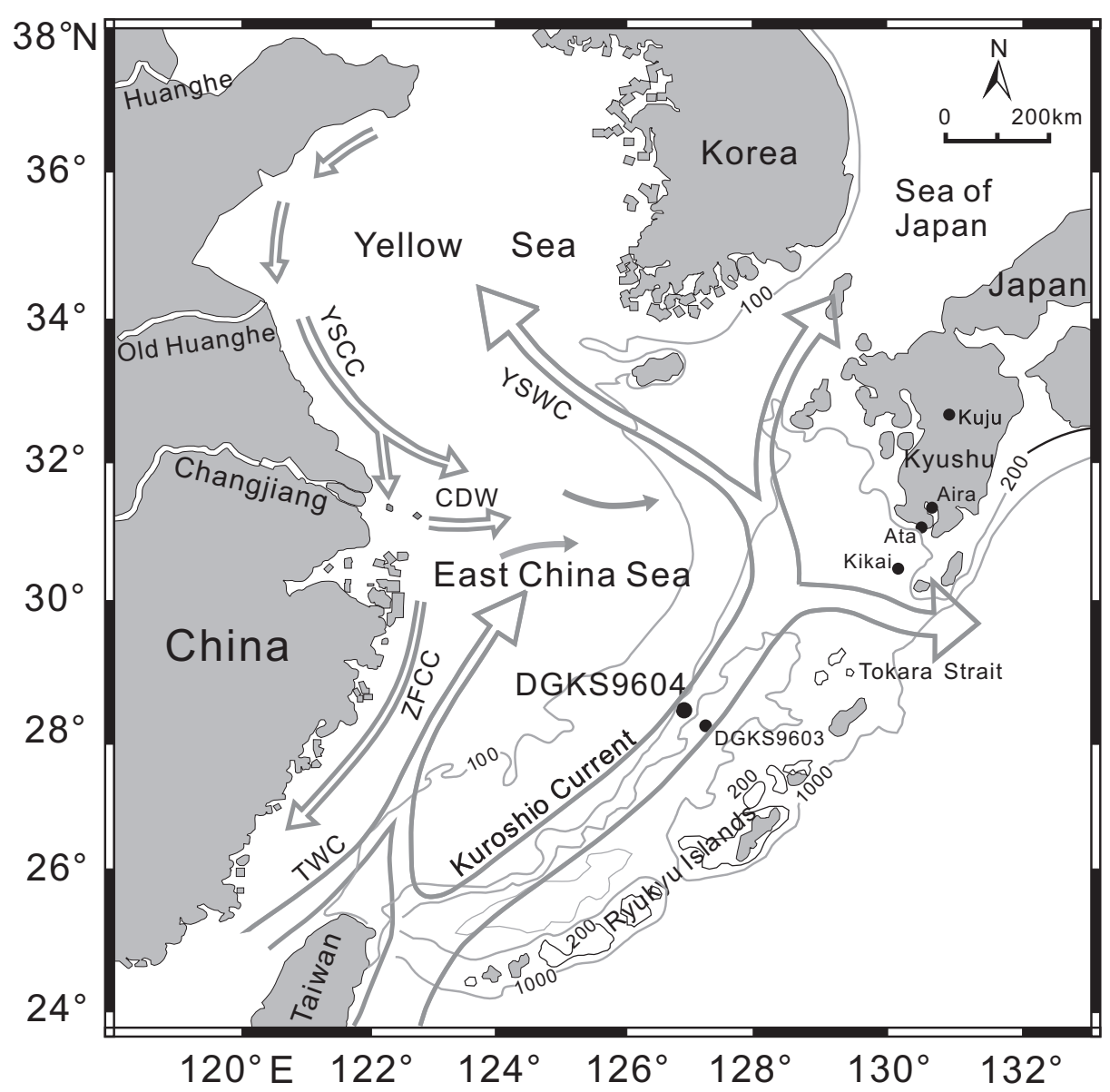




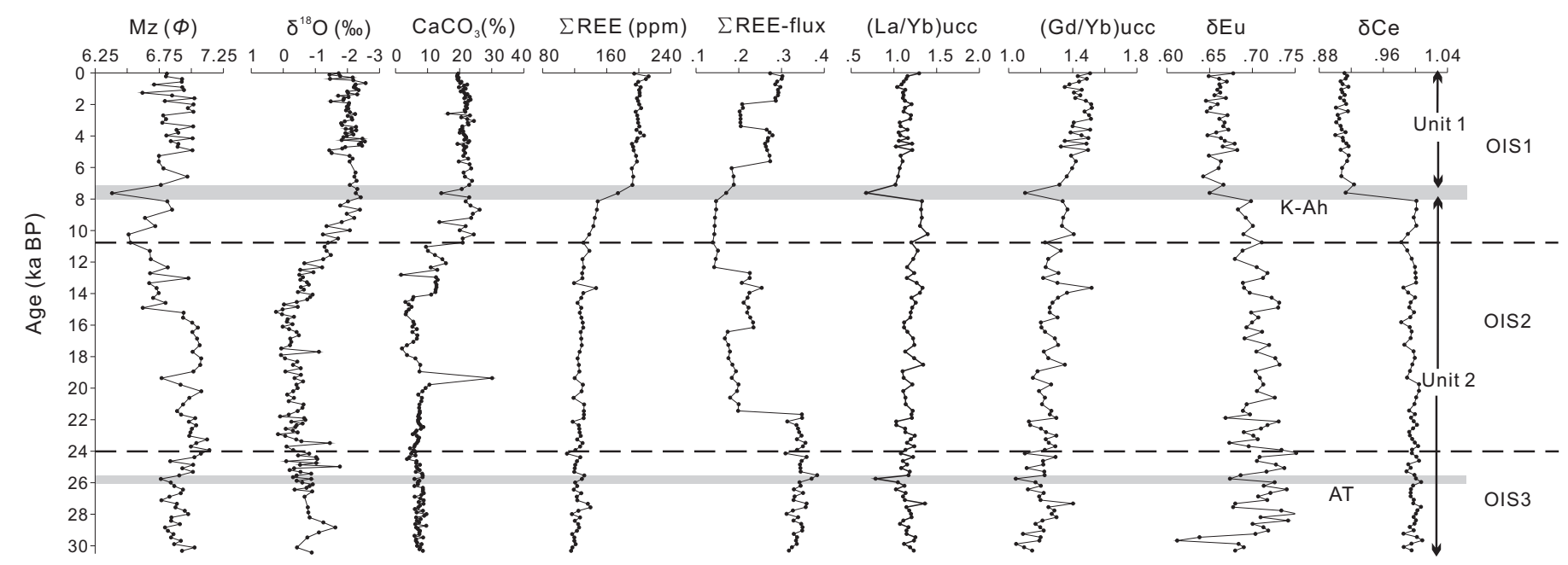




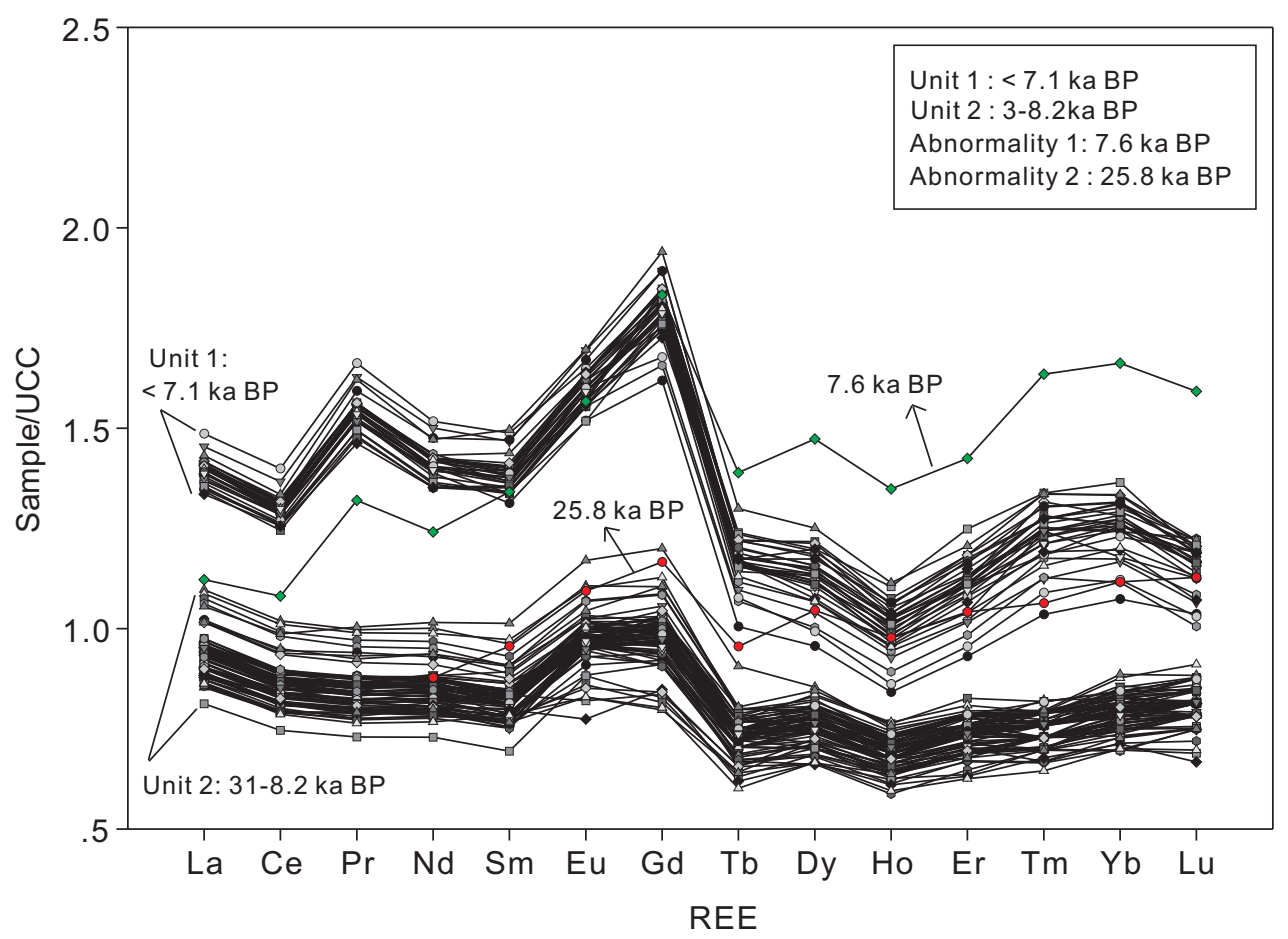



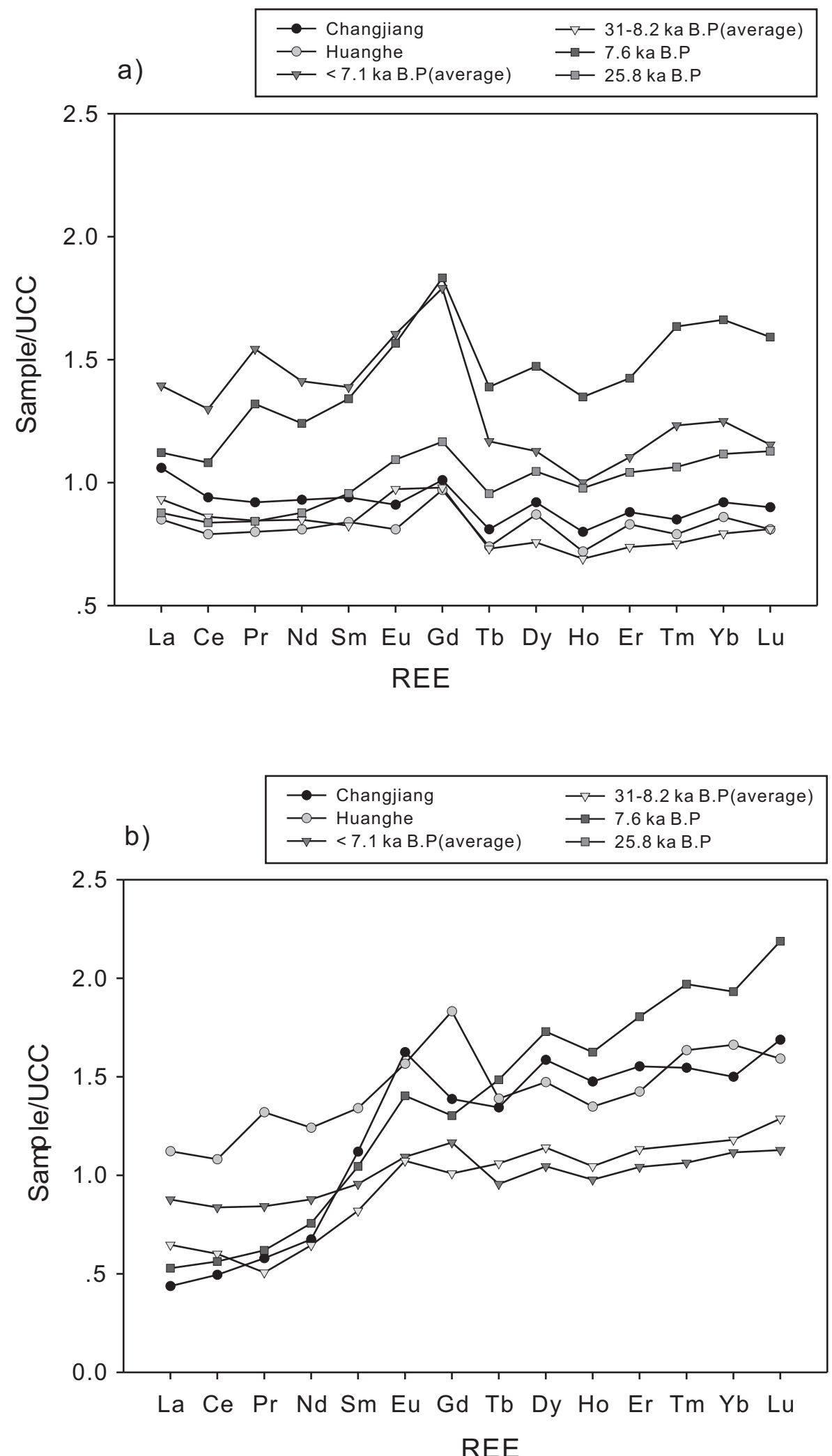

REE 


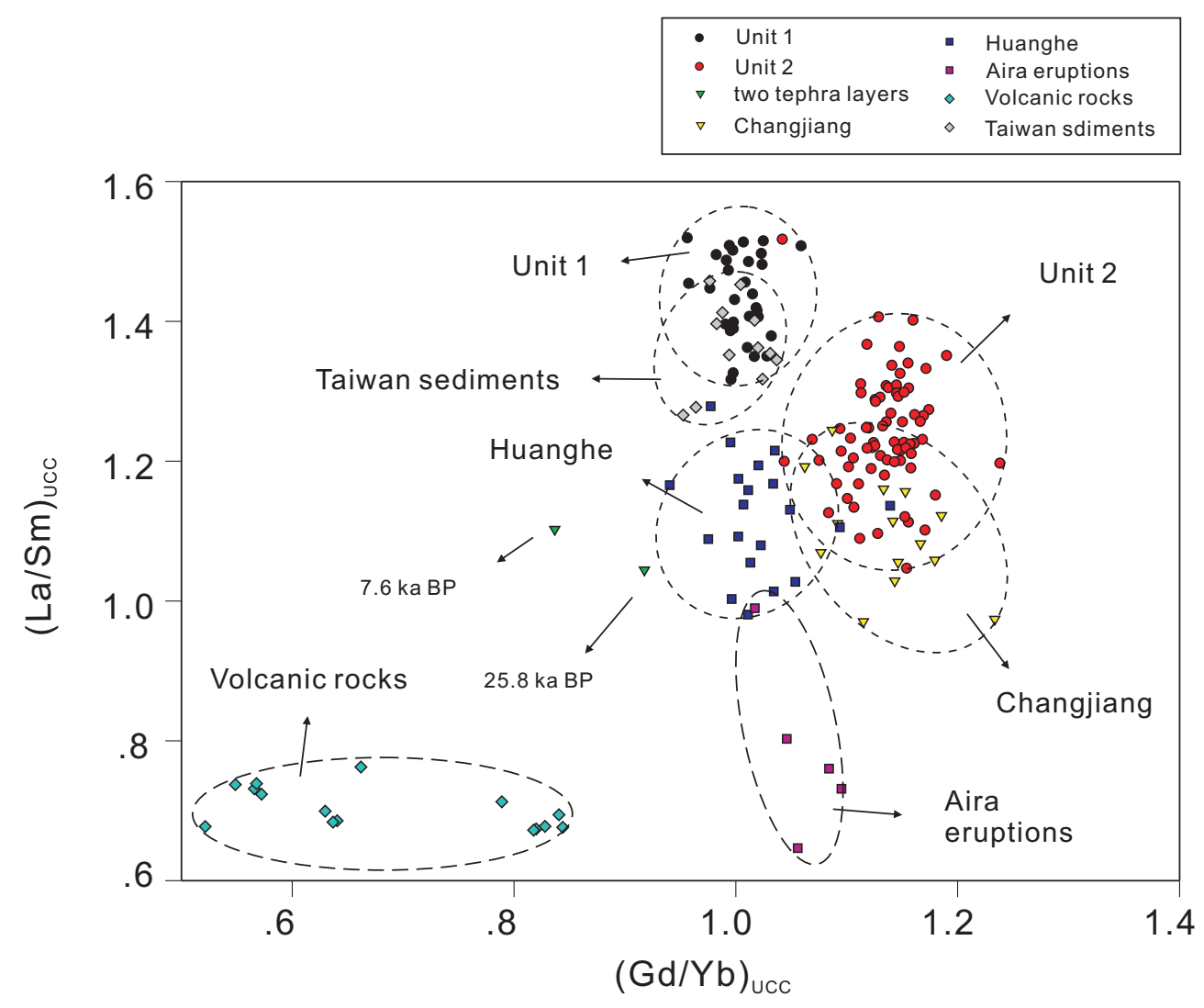

\section{revised Figure 5}




\section{a) LGM}

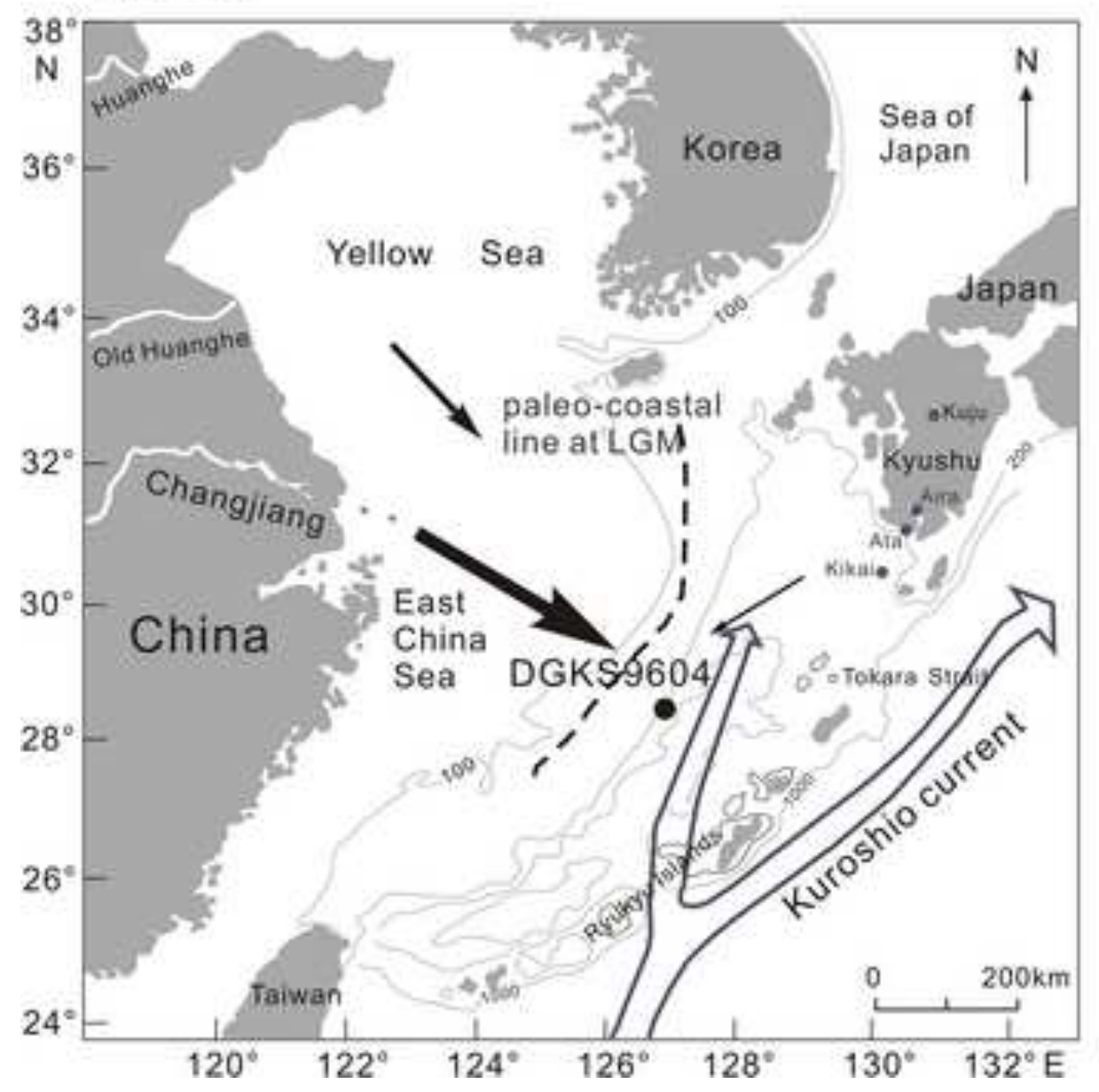

b) 7 ka BP present

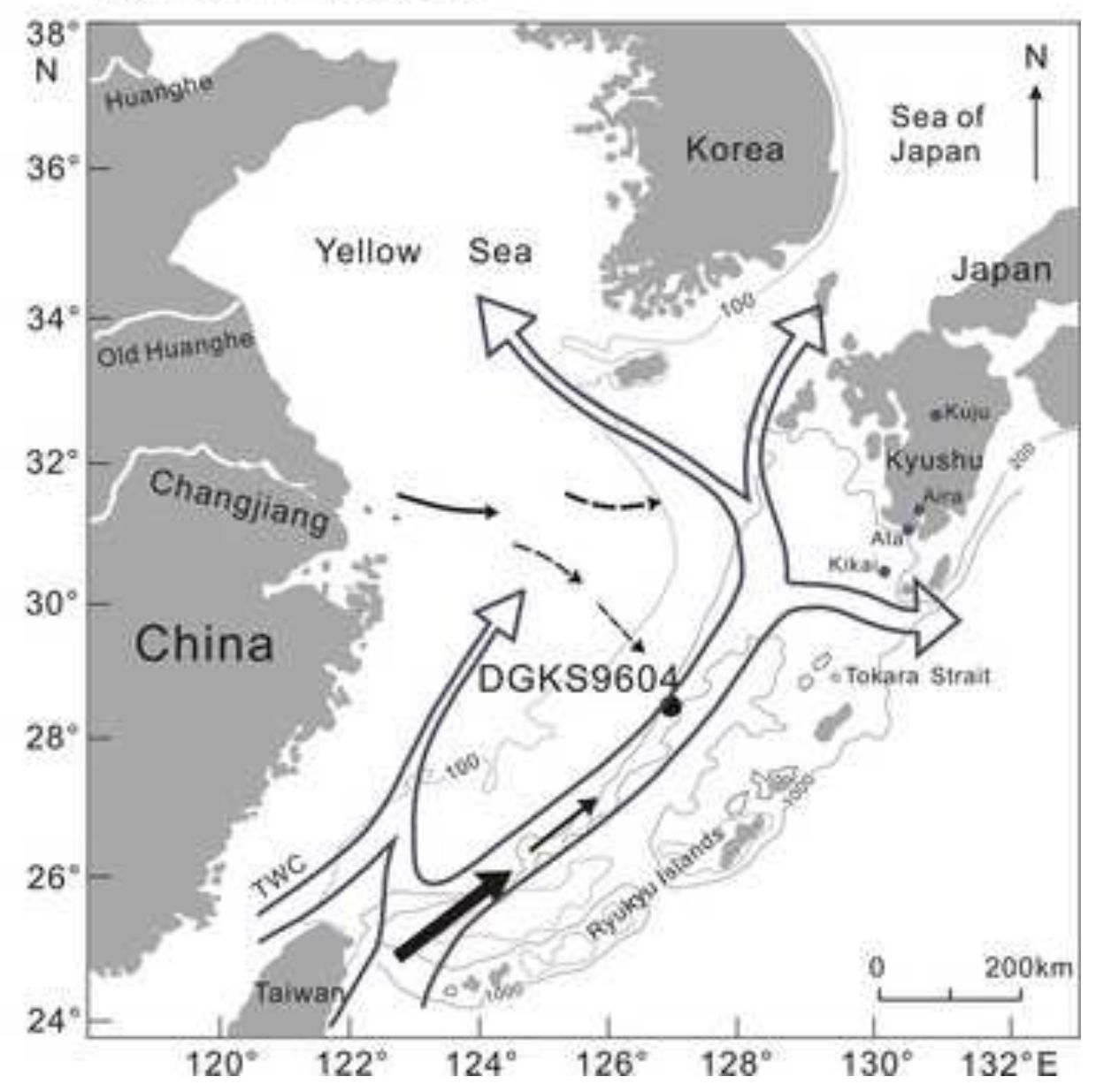


Table 1

Comparisons of rare earth element compositions in Core DGKS9604 sediments with those of upper continental crust (UCC, Taylor and McLennan, 1985), East China Sea sediments (ECS, Zhao et al., 1990), core sediments of southwestern Taiwan (Chen et al., 2007), residual fractions of the Changjiang and Huanghe riverine sediments (Yang et al., 2002), and volcanic rocks of Okinawa Trough (Shinjo and Kato, 2000).

\begin{tabular}{|c|c|c|c|c|c|c|c|c|}
\hline Samples & $\begin{array}{l}\text { Core } \\
\text { depth } \\
(\mathrm{cm})\end{array}$ & $\begin{array}{l}\text { Age } \\
\text { (ka BP) }\end{array}$ & $\begin{array}{l}\sum \mathrm{REE} \\
(\mathrm{ppm})\end{array}$ & $\delta \mathrm{Eu}$ & $\delta \mathrm{Ce}$ & $(\mathrm{La} / \mathrm{Yb})_{\mathrm{UCC}}$ & $(\mathrm{Gd} / \mathrm{Yb})_{\mathrm{UCC}}$ & $(\mathrm{La} / \mathrm{Sm})_{\mathrm{UCC}}$ \\
\hline Unit 1 & $0-142$ & $0-7.1$ & $198.6 \pm 4.8$ & $0.66 \pm 0.01$ & $0.91 \pm 0.01$ & 1.12 & 1.44 & 1.01 \\
\hline Unit 2 & $158-743$ & $8.2-30.3$ & $127.0 \pm 9.3$ & $0.71 \pm 0.02$ & $1.00 \pm 0.01$ & 1.19 & 1.24 & 1.14 \\
\hline Abnormality 1 & 150 & 7.6 & 174.0 & 0.65 & 0.91 & 0.68 & 1.10 & 0.84 \\
\hline Abnormality 2 & 575 & 26.8 & 129.0 & 0.67 & 1.00 & 0.79 & 1.04 & 0.92 \\
\hline Whole core & $0-743$ & $0-30.3$ & $148.4 \pm 33.5$ & $0.69 \pm 0.03$ & $0.97 \pm 0.04$ & 1.16 & 1.29 & 1.10 \\
\hline UCC & - & - & 146.4 & 0.65 & 1.03 & 1.00 & 1.00 & 1.00 \\
\hline ECS & Sea floor & modern & 120.2 & 0.60 & 1.03 & 0.99 & 1.56 & 0.75 \\
\hline Taiwan sediments & $0-2340$ & - & - & 0.65 & - & 1.41 & 1.33 & 0.96 \\
\hline Huanghe & Floodplain & modern & 119.4 & 0.60 & 0.98 & 0.98 & 1.12 & 1.02 \\
\hline Changjiang & Floodplain & modern & 140.6 & 0.61 & 0.98 & 1.15 & 1.10 & 1.14 \\
\hline Volcanic rocks & - & - & 109.6 & 0.76 & 0.99 & 0.37 & 0.74 & 0.62 \\
\hline
\end{tabular}

Note: $\sum$ REE denotes total REE concentrations $(\mathrm{ppm}) \pm 1$ standard deviation; $\delta \mathrm{Eu}$ and $\delta \mathrm{Ce}$ are Eu and $\mathrm{Ce}$ anomalies respectively, and see the text for the calculation. $(\mathrm{La} / \mathrm{Yb})_{\mathrm{UCC}},(\mathrm{Gd} / \mathrm{Yb})_{\mathrm{UCC}}$ and $(\mathrm{La} / \mathrm{Sm})_{\text {UCC }}$ refer to UCC-normalized REE fractionation parameters. Note that the REE data of the Huanghe and Changjiang refer to the leached residues while those of UCC, ECS, Taiwan sediments and volcanic rocks mean bulk compositions. 
